\title{
Chapter 6: The Transnational
}

All the museums analyzed so far operate with a clear national perspective on the Second World War. The museums in New Orleans, Ottawa, London, ${ }^{1}$ Berlin (Topography of Terror), Kraków, and Warsaw focus either on a national perspective, or - as in Kraków - on a national space. The museums in Manchester and Bastogne connect the local and national to the global; the museum in Dresden connects the national (and sometimes local) to the anthropological and universal. In contrast, the three transnational exhibitions analyzed in this chapter - the German-Russian Museum, the Gdańsk Museum of the Second World War, and the House of European History - both surpass and partially maintain the national. As seen in the discussion of the previous museums, transnational museums are situated between strong master narratives that restrict experientiality; closed forms of experientiality that steer visitors into cognitively and emotionally accepting pre-conceived historical interpretations, collective perspectives, and structures; and open forms of experientiality that allow for an active visitor to engage in the interpretation of the past. Transnational memory museums highlight collective perspectives: if and when they employ individual accounts, it is to illustrate collective stories and perspectives.

\subsection{The German-Russian Museum in Berlin-Karlshorst}

The transnational Deutsch-Russische Museum (German-Russian Museum, DRM) in Berlin-Karlshorst features perspectives from Germany and the Soviet Union. The DRM continues to be a unique bi-national institution supported by the Federal Republic of Germany and the Russian Federation. Its joint German-Russian advisory board was established in 1994. The DRM also cooperates closely with other military history and history museums in Germany, Russia, Ukraine, and Belarus. $^{2}$ The museum is located in a historical villa where, on May 8, 1945, the Ger-

1 The gallery "Turning Points: 1934-1945" in the Imperial War Museum in London (from 2014) adds one section on the war in the East to its primarily British perspectives. The "First World War Galleries” from 2014 have a British focus, but feature considerable global segments as well. 2 For a more detailed description of the DRM's institutional history and set-up see Clarke and Wóycicka 2019, 81-82. Clarke and Wóycicka argue that the DRM cannot fully realize its "cultural diplomacy potential (...) as a tool of reconciliation," because of "the continuing salience of the

๑ OpenAccess. ๑ 2020 Stephan Jaeger, published by De Gruyter. (cc) BY-NC-ND This work is licensed under the Creative Commons Attribution-NonCommercial-NoDerivatives 4.0 License. 
man forces signed their official 'Eastern Front' surrender at the end of the Second World War. ${ }^{3}$ The first permanent exhibition of the DRM opened in May 1995 (Jahn 2003). On April 24, 2013, it reopened with a redesigned and updated exhibition of about 1,000 square meters. ${ }^{4}$ The current permanent exhibition is presented in ten chapters, most of which are located on the first floor. ${ }^{5}$

As seen in the Bundeswehr Military History Museum (MHM) and in the Topography of Terror, the exhibition uses an open documentary style that leaves considerable room for the visitor to interpret facts, images, and objects. This leads to a secondary experientiality operating more historically toward the simulation of collective perspectives and historical spaces, rather than the simulation of abstract concepts and structures, as seen for example in the MHM. In the case of the DRM, this includes the perspectives of Germany and the Soviet Union. The museum's historical focus leads to the abstract simulation of the impacts of war. Like the exhibitions discussed in the previous chapter, the DRM does not attempt to create the illusion that the past can be 'experienced' as such. Instead, it simulates structural experiences that rely on the constructed collective perspectives of specific groups. These include those of Soviet prisoners of war, those found in the interactions between Germans and civilians in the occupied Soviet Union, or those on the Soviet and German home fronts. Herein lies the DRM's difference to the other museums under discussion, which either express the perspective of a nation and subgroups within a nation, or create a general collective perspective, e.g. the victim or the soldier. In contrast, the DRM establishes a transnational effect, which allows the visitor to reflect on the collective memories of nations and national subgroups. This also provides the visitor with room to interpret and understand the similarities, differences, and

memory of war in the national context” $(2019,82)$. Germany's prototypical cosmopolitan memory regime clashes with the Russian nationalistic one (Clarke and Wóycicka 2019, 88-89).

3 The first museum in the villa was inaugurated in November 1967 for the fiftieth anniversary of the October Revolution as the Museum of Fascist Germany in the Great Patriotic War 1941-1945 (Museum der bedingungslosen Kapitulation des faschistischen Deutschlands im Großen Vaterländischen Krieg 1941-1945).

4 On the ground floor, the DRM displays historic rooms from the surrender including the office used by Marshal Zhukkov, the surrender room, and a diorama depicting the storming of the Reichstag from the Museum of Fascist Germany in the Great Patriotic War 1941-1945. The grounds outside the building remain as they were designed in 1967, with a "Victory Park" including a memorial of a T34 tank on a pedestal and a selection of Red Army tanks and artillery. 5 An installation about the memory of the war can be found on the ground floor. The final room "Conclusion, and the Consequences of War" is located in the basement. It is evident that the exhibition works with limited space. For the structure of the exhibition see also director Jörg Morré's introduction to the museum catalog (2014). 
universalities between varied national experiences. This creates the interpretative effect of experientiality that allows the visitor to compare the collective wartime experiences of both nations, whether it be the treatment of enemy soldiers or civilians, the will to survive, forms of resistance, atrocities, political movements, societal advancement, journalism, or forms of remembrance. The DRM uses three major techniques in employing the transnational: tangencies and interactions, parallel themes and structures, and parallel collective perspectives or spaces. The transnational allows for the expression of constellations. In this way, the national - or other elements of collectivity comprising the national - is not diminished or eradicated for the sake of a higher collective, i.e. the transnational. Instead, the comparative approach of the DRM brings out certain qualities of national and group identities and in doing so, expresses the transnational as secondary experientiality. Namely, it enables the visitor to interpret the simultaneity of constellations, perspectives, and spaces.

The first dimension of the transnational approach is to demonstrate the tangencies of and interactions between both sides. These are visible, for example, in the first room on the upper floor of the museum's permanent exhibition. This room is entitled "Germany and the Soviet Union 1914-1941," and creates a temporal structure that adheres to the Soviet perception of the war's duration instead of presenting the beginning of the war as the attack on Poland, as is the norm in German museums. This allows the museum to highlight the Soviet-German relationship. Specific tangencies are represented through text, images, and objects and include the Brest-Litovsk Peace Treaty in early 1918, the covert cooperation between Germany and the Soviet military in the 1920s and early 30s, proSoviet communists in Germany, and the Molotov-Ribbentrop Pact and its effects. Other tangencies emerge through the ways in which one side perceives the other; for example, the museum presents documents providing evidence of the early roots of anti-Bolshevist ideology in Nazism, but also within Christian circles.

As a second dimension, the museum employs structural parallels between the two countries in single exhibits or thematic sections. In the second, fairly traditional exhibition room providing a chronology of the war, for example, the visitor finds not only uniforms and weapons from both sides - common in most war and army museums - but also sections with Soviet and German objects. These include sections such as "Injury and Death," "Leisure Time," and "Communicating Home." Unlike in most war museums, this contrastive approach allows the visitor to reflect on the simultaneities expressed by these objects - such as field post letters from soldiers to their mothers in both countries - or differences such in the identification case and tag from both countries. Consequently, visitors have the opportunity to judge for themselves whether individual objects express a national, transnational, or universal concept. 
The most significant transnational exhibit in this room is the section on war photography. Here, the DRM emphasizes the importance of contextualizing war photography in three sub-sections: Soviet photojournalist correspondents, German photojournalist correspondents, and German amateur photography. ${ }^{6}$ The visitor learns that official Soviet photo correspondents had more freedom in the actual selection of photographs chosen for publication than their German counterparts. The museum clusters its three sections around historical objects, partly belonging to the photographers, and the published photographs of three photographers: Timofey Melnik, Benno Wundshammer, and Wilhelm Meyer. A digital photo album station at the end of the display presents and captions twenty war photographs from each photographer. The museum's transnational approach allows the visitor to understand different dimensions of war photography as well as whether it operated differently according to function (public-private) or nation (Soviet-German). This is, of course, strongly guided by the DRM's selection. The private, amateurs soldier's shots are mainly closeups as well as scenes from behind the front and post-battle scenes. On the other hand, both official photojournalist correspondents have produced aerial panoramic shots, close distance shots, and scenes shot during the battle. The dead, prisoners, and refugees from the other side are mainly presented during winning advances; similarly, the cost of war among one's own soldiers and population is more likely to be depicted from the perspective of the aftermath of a battle in occupied or liberated territory. Symbols of victory play a major role in the photography from the Soviet side. Images taken from the air by Wundshammer could be read as expression of German technological superiority, as demonstrated by the cover of the military magazine Signal entitled "Stukas diving on Stalingrad." Visitors see images of German POWs from the Soviet point of view and vice-versa and must wonder whether they had different or similar fates. The visitor learns about how photography can be used and can thereby reflect upon its functions, possible truths, and distortions. In this way, a structural experience is encouraged in the photography section as well as in the reading of photographs assembled throughout the permanent exhibition.

The contrasting of collective perspectives is the third and most important technique used in the creation of a transnational museum. In rooms 3 and 7 , the exhibition addresses the theme of Soviet and German prisoners of war;

6 This sub-section also notes that an equivalent of private photography did not exist on the Soviet side because of stricter regulations and a lack of cameras.

7 The DRM also presented a special exhibition on Wundshammer as a propaganda photographer from November 2014 to February 2015, allowing visitors to further understand how photographs were produced and functioned as a medium during the Second World War (Kindler 2014). 


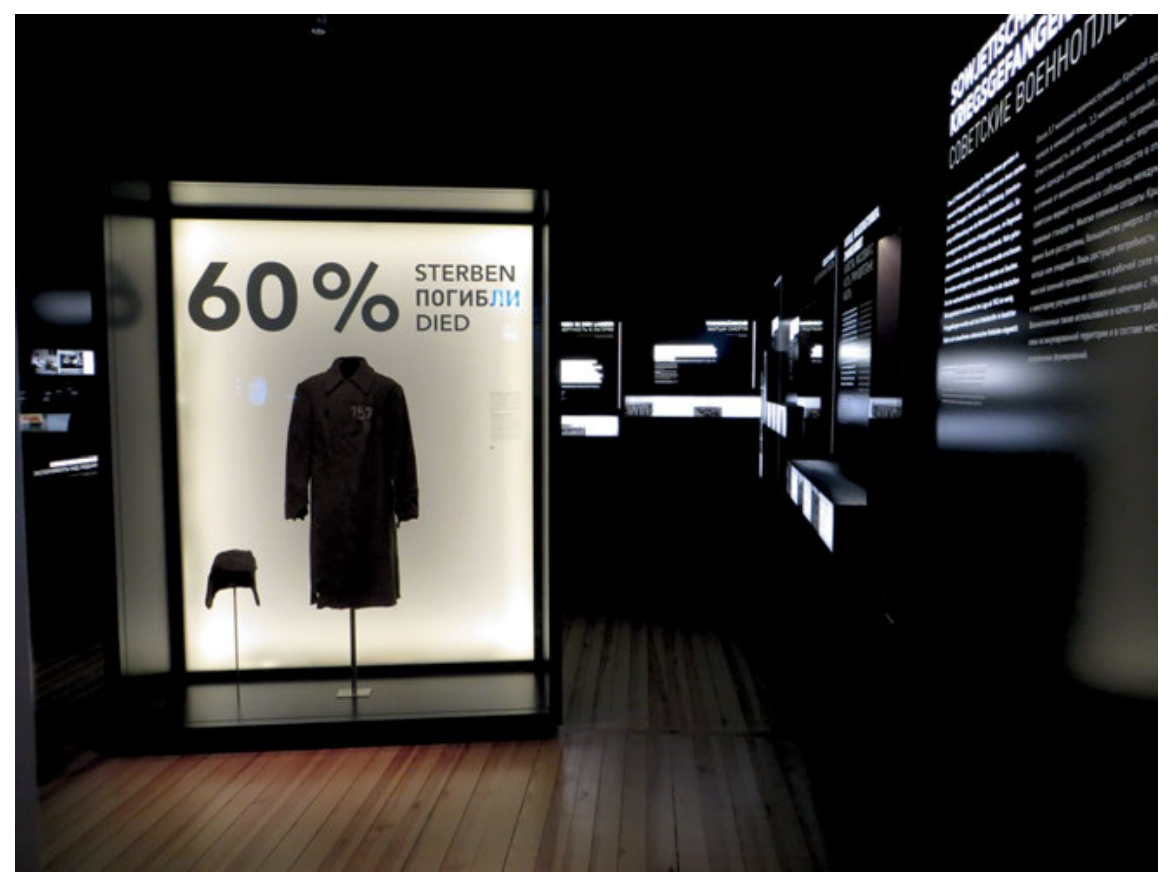

Fig. 20 Room "Soviet Prisoners of War." Permanent Exhibition. Deutsch-Russisches Museum (German-Russian Museum) Berlin-Karlshorst (Photo: Author, 2013, courtesy of Deutsch-Russisches Museum).

room 4 features Soviet territory under German occupation, while room 9 features the Russian occupation of Germany and Berlin and the final days of the war. Additionally, room 5, entitled "The Soviet Union in War," and room 8, entitled "The War in the East and German Society," both place their focus on the two countries' respective home fronts and civilian populations. The effect of the museum's contrastive technique can be demonstrated through a comparison of the two rooms thematizing prisoners of war. The small darkened room on Soviet prisoners of war features an installation displaying a coat and cap of an unknown Soviet POW with " $60 \%$," written in large font - referring to the number of Soviet POWs who died in German captivity (in contrast to $3.6 \%$ of West European POWs, see fig. 20). ${ }^{8}$ Visitors are prepared for this topic in the section at the end of room 1, where they enter a black cube with dimmed lights, which focuses

8 An earlier, considerably briefer version of analyzing this room was published in Jaeger 2019, 64-65. 
on German war planning (see also Jaeger 2017a, 34-35, 2019, 64). The cube combines quotations from Nazi and SS leaders as well as leading Wehrmacht officers. Included here is commentary on the politics they planned to implement in the East and eleven résumés of German leaders, including Hitler, Rosenberg, and Jodl, who were involved in the planning of the invasion of the East. It also contains facsimiles of German policies and directives, propaganda flyers, and a map of grain and livestock supplies to be used to feed the advancing German army. The cube leaves no doubt about German extermination policies and the involvement of the Wehrmacht in their execution. It creates a structural experience by simulating the visitor's entry into the collective mind of the planning of a campaign to destroy the Soviet people.

This secondary experientiality corresponds to the Soviet prisoners of war room, which displays the suffering and fate of Soviet POWs through a variety of themes: planned murders, death marches, camps, forced labor, human experimentation, and collaboration. The museum presents these themes in white font, contrasted against the black walls of the rooms. At the top of each thematic section, the museum provides a section header; at the bottom - as in most rooms in the museum - a narrow strip of captioned black-and-white photographs is located underneath the different display cases. The main space in-between the section headers and photographs contains large quotations from German organizers, occasional small display cases with artifacts and documents, some film footage, and digitally projected photographs. The room is supplemented by the first two audio-visual stations (out of a total of fifteen in the museum) featuring the biographies of certain wartime actors and victims, told in the voice of a third-person narrator. This is supported by a slideshow of images and photographs: in this case, of two Russian prisoners of war. From the German perspective, the visitor learns about the atrocities and crimes perpetrated against Soviet POWs, structurally simulating the different dimensions of these crimes. The introductory panel is located following an introductory survey text supplying facts and numbers; it is entitled "Murder, Countless Deaths, Forced Labor." This panel provides details on the commissar order instructing the Wehrmacht that any Soviet political commissar in the Red Army had to be executed, the killing of other military officers, of soldiers on racial grounds, and of soldiers who were separated from their units. It also informs about the deaths of thousands of prisoners during marches and in camps due to hard labor and malnutrition.

The photo strip at the bottom of this panel leads the visitor from the arrest of Soviet soldiers, to the interview of a political officer, and finally to a photo that was originally entitled "A Jewish Commissar digging his own grave." This sequence of photographs slowly establishes factual evidence of the murders. The subsequent section is called "Deliberate Murders." A quotation by Security Po- 
lice and SD chief Reinhard Heydrich is the focal point of the panel, supplemented by numerous facsimiles of German killing policies and orders: "In particular, the following groups must be identified: all leading officials of the state and the party, ... all former political commissars in the Red Army, ... the leading people of Soviet business, the Soviet-Russian intelligentsia, all Jews, all people who prove to be revolutionaries or fanatic communists." 9 The supplementary documents add depth and authenticity to the killing policies on display. An example of this is a letter from Ralf Lattmann, Chief of the Army High Command legal department, to the Armed Forces Supreme Command, asking whether political officers at the company level were also to be killed; the museum also includes their affirmative response. The photo strip depicts the arrests of people belonging to different target groups, such as an 'Asian looking' Soviet POW or one with a Jewish star. This allows the visitor to visualize the groups targeted for murder as laid out in the Heydrich quotation. Another photograph shows a captured Soviet female soldier, highlighting how German soldiers loathed and often killed women soldiers on sight. The section then shifts to partisans, death marches and mass deaths in the camps, and forced labor. To counterbalance the perpetrator gaze, two audio-visual stories focus on the survival of a woman and a man in the camps and their life trajectories after the war. In summary, the museum creates a structural reality concerning the fate of Soviet prisoners of war from the perspective of the perpetrators. Structurally, the visitor starts to understand the horrible fate and evidentiality of the crimes committed against these POWs in different phases. Although the DRM presents historical facts and evidence, this room creates a structural impression of today's cultural memory of the war. This leads to the experientiality of German atrocities through all kinds of historical actions and agents.

In contrast, the small room on German prisoners of war - technically the wall of a hallway between two larger rooms - is fashioned around an enlarged poster of German POWs and a large map showing the different internment camps where they were held. These items are supplemented by a photo strip exemplifying activities and living conditions in the camps as well as numerous display cases holding small objects such as maps, documents, and everyday items used by the POWs. The exhibition text underscores the lack of legality concerning the ways in which many prisoners were declared war criminals in rushed trials in 1949, in order to keep their labor in the Soviet Union. However, this text also highlights that most of the POWs were treated in accordance with international

9 Translation S.J. The text in the DRM is in German and Russian, whereas the English text contains a shorter abbreviated version, so that for example the quotations are not translated. 
law. The exhibition employs a documentary representational style, and the DRM forgoes the possibility of adding audio-visual documents on German prisoners of war. Although this section is made up of only one display wall with two display cases, it is significant for understanding the effect of the museum's consequent transnational approach: it allows the DRM to present historical differences and universalities of POW's suffering on both sides so that the visitor can approach the theme from different angles. The museum renders the point at which the treatment of POWs crosses over in war crimes undeniably clear. On the one hand, visitors can see the hardships faced by German POWs in the Soviet Union, but on the other, realize this treatment is not comparable to the killing and exploitation perpetrated against Soviet POWs by Germany. One could also argue that a transnational approach can also be too narrow, since it does not reflect upon the fate of other POWs and forced laborers in the Soviet Union.

This structural approach of simulating the impact of war is generally cautious in creating empathy. Whereas the DRM tells stories illustrating the fate of Soviet POWs, their voices are not focalized and instead merely reported. Why does the museum avoid giving the victims more of a voice? Furthermore, why does it not create a parallel room from the perspective of Soviet POWs? Clearly, the DRM has limited space in its historical rooms. The museum could have underlined the difficulties found in representing the suffering and stories of these POWs; and it could have related to the fact that these victims had a hard time being recognized in the Soviet Union. The DRM is even more cautious in creating empathy with perpetrators. Their institutional and systemic involvement is clear: the visitor observes events through their collective gaze as in the ToT, however, no discussion about individual responsibility, guilt, and motivations beyond the criminal campaign takes place.

The key question is whether the museum creates a transnational perspective that merges different national perspectives, or whether it simply narrates the perspectives of two different states and their sub-groups. Mostly, the DRM succeeds in doing both. While visitors learn about nation-specific narratives, the museum's transnational approach allows them to develop an understanding that goes beyond traditional national perspectives. This is demonstrated, for example, through the juxtaposition of the two POW rooms. Similarly, room 5 in the exhibition, entitled “The Soviet Union in War," stages the enormous collective will possessed by Soviet citizens in withstanding the Germans, signified by their industrial effort, patriotic propaganda, partisan fighting, and the fight for survival in besieged Leningrad. The visitor is made to understand this further both through the radio address of Foreign Minister Vyacheslav Molotov on June 22, 1941 that greets them in Russian upon entering the room, and through the sound of the metronome beating in Leningrad, which can be heard in the section 


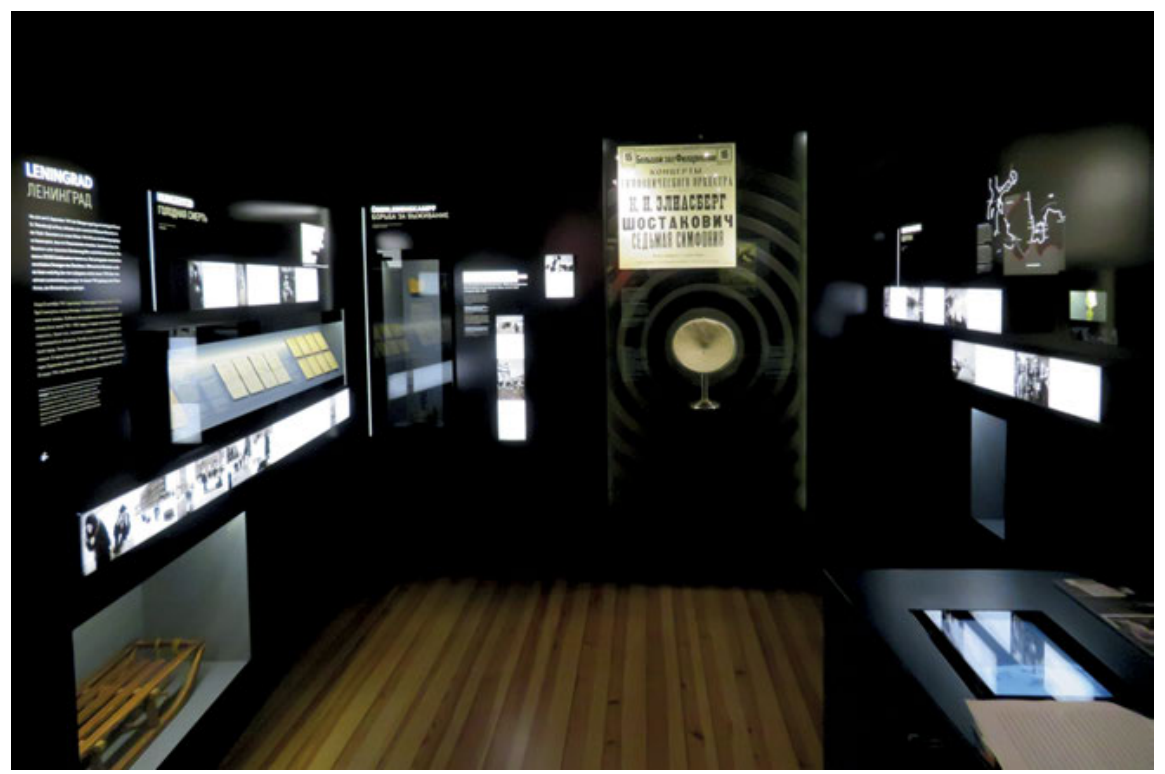

Fig. 21 Section “Leningrad.” Permanent Exhibition. Deutsch-Russisches Museum (GermanRussian Museum) Berlin-Karlshorst (Photo: Author, 2017, courtesy of Deutsch-Russisches Museum).

detailing the siege of Leningrad (see fig. 21). At this point in the museum, visitors will have just emerged from the two perpetration rooms concerning Soviet POWs and German atrocities during the occupation of Soviet territory (see also Jaeger 2017a, 35, 2017c, 154-155). They have therefore already been experientially immersed in questions of survival. Whereas a straightforward section on the Leningrad siege might exclusively capture the suffering of the Russian people and their will to survive, the transnational approach of the DRM contextualizes this historical episode in a way that surpasses its portrayal as an isolated event. Therefore, visitors are steered away from simply lamenting the death, atrocities, and costs of war stemming from the siege: instead, the exhibition creates a secondary experientiality surrounding collective behavior. This transnational approach prevents the simple repetition of Soviet or German wartime propaganda and at the same time allows for genuine simulations of collective perspectives.

In room 8, visitors are greeted by a quotation from Joseph Goebbels and an enlarged poster depicting a woman being instructed on how to use a Panzerfaust. This ironically expresses the desperation of the Nazi regime in the final days of the war. It is supported by a scene from the last edition of the Wochenschau (German 
weekly), showing Hitler honoring members of the Hitler Youth and Volkssturm in the garden of the Reich Chancellery. More importantly however, it creates a structure running parallel to that depicting the Soviet will to survive, which the visitor will have already experienced. At the end of the room, the visitor is exposed to the collective fanaticism among the German people continuing to fight, despite Stalingrad, the Air War, and the flight from East Prussia. The visitor is also shown the ways in which the Nazi regime manipulated these feelings among the German populace; the mobilization of the Volkssturm is its last propagandistic step. The first display case highlights how the Nazi regime established the belief that Russians were subhuman, and that additionally there was the need for a war against Stalin. In order to do so, this display employs titles of publications and posters. This helps visitors experience to a point - with reflective distance through contextualizing captions and text panels - how the war of ideology developed and how it led to the fanaticism of at least a portion of the German population at the end of the war. The DRM counter-balances this propaganda effect with two audio stations featuring the voices of resistance fighter Herbert Baum and his group and Meta Klibansky and her family, who were deported and died in Maly Trostinets. A display case, showing a montage of quotations by German citizens who knew about the atrocities in the East, also acts as a counterbalance: it is evident that there was no teleological German fanaticism. As in the room on Russian civil society, the visitor can decide on how different forms of collective will and identity are formed, how propaganda works in creating causes to defend one's country, and how the image of the enemy is constructed.

The last room on the upper floor depicts the liberation of Germany by the Red Army, following a brief interlude on the discovery of Nazi crimes and death camps. It also charts the early months of the Soviet occupation, with a particular focus on Berlin. It is almost completely designed from the Soviet perspective. The rape of German women is represented on a panel entitled "Abuses," dominated by a quotation from the military prosecutors of the $1^{\text {st }}$ Belorussian Army Group reporting the arrest and conviction of a Red Army soldier for the rape of a 15-year-old girl on April 22, 1945. The museum provides an additional explanation, which contextualizes both the rapes and the explicit change in policy that occurred on April 20,1945, asking for the ceasing of crimes against the German civilian population and their better treatment in order to create a better climate during the occupation. In a small display case that is part of the panel, the visitor finds four handwritten notes about the consequences of the mass rape from the medical records of the Charité in Berlin in 1945, accompanied by a factual contextualization of the evidence detailing what data about the rapes is known and what remains unknown. The visitor can immediately draw a comparison between these displays and those found in room 4 concerning German 
crimes against Russian civilians during the occupation of Soviet territory. The extent of the parallels between these two rooms is left open to the visitor, although the considerable difference between the German and Soviet perpetration and suffering is evident. ${ }^{10}$ In other words, the DRM transnationally creates constellations of crimes, facts, and motives without explicitly judging them. This allows visitors to comprehend national experiences and collective national perspectives structurally, so that a competitive memory framework can potentially be overcome. The visitor can understand the circumstances particular to the national memories presented; however, the poietic staging of transnational constellations also allows for an experientiality that surpasses competition. Indeed, this experientiality adds insight that a national representation, whether commemorative or documentary, could not achieve. Although the DRM represents a historically specific world, it moves beyond this specificity by creating a universal experience through different collective gazes focusing on experiences, structures, and moods. Within the limitations of its political framework (see also Clarke and Wóycicka 2019), the museum simulates total war and supersedes national interests in displaying the repercussions of war, despite being based on the wartime experiences of two opposing states. In other words, it operates transnationally, surpassing the nation state while displaying its continued relevance.

\subsection{The Museum of the Second World War in Gdańsk}

Whereas the German-Russian Museum is a bi-national museum, whose transnational memory methods allow for the expression of secondary experientiality, the Museum of the Second World War (MIIWŚ) in Gdańsk operates as a hybrid of national and transnational museum that combines a strong master narrative of Polish victimhood and German-Soviet perpetratorship with a secondary experientiality simulating the effects of total war. To understand the MIIWŚ's inherent tension between master narrative, experientiality, and transnational memory, one needs to understand its genesis and the intense and highly politicized memory battles it has generated. ${ }^{11}$ The museum was established by the state of Poland in 2008 and opened on March 23, 2017, after an impassioned memory debate. In April 2016, the Polish Ministry of Culture and National Heritage

10 Following the thesis of cultural diplomacy's restrictions in the exhibition (Clarke and Wóycicka 2019) one can certainly argue that the DRM is very cautious in presenting Soviet crimes and perpetration, which reduces the comparative potential of the exhibition considerably.

11 See also Clarke and Duber $(2018,8)$ for the intended balance between nationalistic and transnational / comparative narratives. 
announced a new administrative structure, in which the museum would be merged with another new museum. This other museum has yet to be constructed, will be located on Gdańsk's Westerplatte peninsula where the Second World War began, and will focus solely on the events in Poland during 1939. Only two weeks after the opening and after a year of court battles, the Polish Ministry of Culture and National Heritage replaced founding director Paweł Machcewicz with government protégé Karol Nawrocki. This was done with the intent of creating a more Polish, heroic, battle-oriented museum and a less civilian-based, transnational museum - and in spite of the protests from Polish and international historians as well as the city of Gdańsk, against the Polish Federal Government's interference. ${ }^{12}$ These memory battles center on whether Polish public history should follow a nationalistic-heroic trend of establishing a post-Soviet Polish identity, or whether it should create a transnational pro-European discourse. ${ }^{13}$ At the time of writing, the majority of the exhibition remains the one that was designed by the previous director's team. ${ }^{14}$ However, this political debate has shown how easily the narrative message of a museum and the ideology behind it can shift according to a change in political leadership, especially if that leadership values memory politics. The original museum can be categorized as a

12 For an overview in English see e.g. Donadio and Berendt 2017; Ciobanu 2017; Clarke and Duber 2018, 9-12. For an English discussion of the museum's transnational or global concept see Snyder 2016. Former director Paweł Machcewicz (2019 [2017]) provides the most detailed history of the development of the museum, with focus, of course, on the change of directors, especially 117-227 regarding the 'battle' between the former director and the Polish Ministry of Culture and National Heritage and the governing Law and Justice Party (PiS). For a shorter summary in English see the interview by Etges and Zündorf 2018 and the article by former museum researchers Anna Muller and Daniel Logemann (2017); in German see Logemann and Tomann 2019. For a non-Polish source on the rhetoric of the new museum leadership, see the interview by the German radio station MDR with the new director: "Interview mit dem neuen Chef des Danziger Weltkriegsmuseums, Karol Nawrocki” (MDR 2017).

13 Jörg Hackmann (2018, 595-596) notes that the museum was, from its beginning, a political project; see also Clarke and Duber 2018 and Siddi and Gaweda 2019. The latter argue that "the predominantly national (Polish) agents driving the creation of the museum in fact constrained the transnational focus of the project from its beginnings" (258). They point out that Machcewicz's appointment also contributed to the politicization of the debate around the museum (Siddi and Gaweda 2019, 261).

14 The dozen or so changes that were recognizable during a museum visit in April 2018 are analyzed throughout this chapter and in chapters seven and eight below. Unless specifically noted, this book discusses the original exhibition. See also for the new director's description of these changes Łupak 2017. Because of interference with the copyright of the original museum, its creators are suing the current museum management (Newsweek Polska 2018; Logemann and Tomann 2019; Siddi and Gaweda 2019, 267). 
transnational narrative history museum, with elements of experiential and ideas museums. ${ }^{15}$ The museum planners have pointed out that despite the museum's scenographic design and its considerable use of multimedia technology, authentic artifacts - all from 1939 to 1945 - remain the backbone of the exhibition. ${ }^{16}$ The exhibition is divided into three main narrative blocks "The Road to War," "Terror of War," and "The Long Shadow of War," which are then divided into eighteen sections varying between one and eight rooms per section. ${ }^{17}$

Comparing the transnational approaches between the MIIWS and the German Russian Museum reveals a similarity in their general chronological presentation. ${ }^{18}$ However, the MIIWŚ exhibition works simultaneously as a national and as a transnational museum. It uses two angles that shape the exhibition. On the one hand, it creates constellations about human violence and suffering, particularly of civilians in the Second World War, while also including sections on the everyday-life of soldiers. Military campaigns remain an afterthought for the

15 The museum building is located in the district of former Wiadrownia (Eimermacherhof) that was completely destroyed at the end of war. It was designed by the architectural studio Kwadrat. "The main building is located underground while only a leaning tower, half red brick and half glass, extends above ground. (...) Its glass structure symbolizes the life that won over death, the light of peace that won over the darkness of war, and finally the modern present and future that dominates over the difficult past” (Muller and Logemann 2017, 88; see also fig. 22). The permanent exhibition is presented in about 6,000 square meters on level -3 , around 14 meters underground (Machcewicz 2019 [2017], 75). The museum varies the size, height, and light of rooms, which allows for numerous experiential effects that can affect the visitor emotionally: for example, there are chapel-like effects in certain rooms on civilian suffering and the feeling of walking through the underground of an occupied city, whose life is happening above the visitor. The design of the exhibition was developed by Tempora, the same Belgian firm that designed and manages the Bastogne War Museum.

16 Machcewicz (2019 [2017]), 62; Muller and Logemann 2017, 85-86. Machcewicz describes in detail how the museum's collection of 40,000 artifacts, of which 2,000 are displayed in the permanent exhibition, was established (2019 [2017] 62-75). See also the summary of the permanent exhibition in Heinemann 2017, 458-481.

17 See Machcewicz, (2019 [2017]), 37-91, for the genesis of the actual exhibition, its objects, and design strategies. See Rafał Wnuk et al. 2016; Machcewicz 2011, 165-171 for the original narrative concept of the exhibition. See also Muller and Logemann 2017, 88-94 for the concept of the exhibition. Joachim von Puttkamer (2017) wrote one of the most extensive reviews describing the actual permanent exhibition from a historian's point of view. He emphasizes the museum's ability to access the past of the war through themes instead of historical events (12). See also the historian's debate between Marcin Kula and Piotr Majewski (2017), who argue about the possibilities and limitations of academic reflection and analysis in a narrative and experiential museum.

18 See also the reflections on adjusting the exhibition concept from a thematic to a chronological concept so that visitors can more easily orientate themselves (Machcewicz 2019 [2017], 84). 


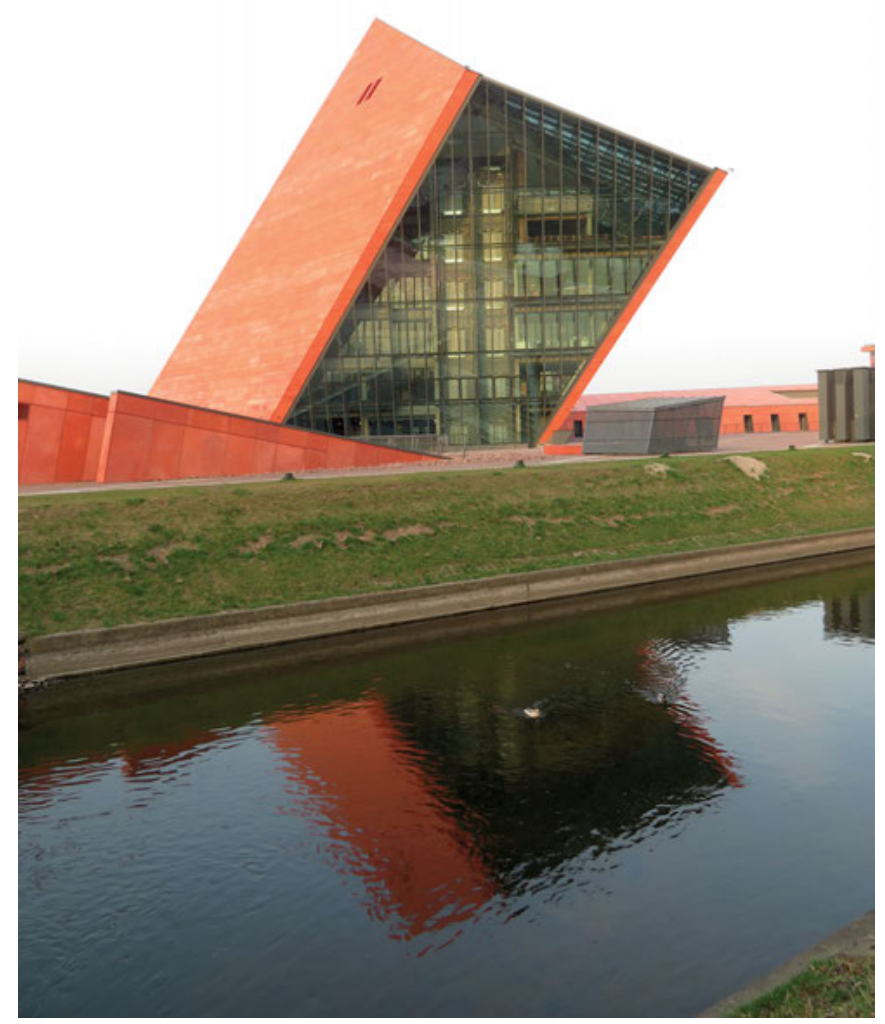

Fig. 22 Outside view of Muzeum II Wojny Światowej (Museum of the Second World War), Gdańsk (Photo: Author, 2017).

museum. These constellations work on the European level, sometimes placing strong emphasis on Central and Eastern Europe, and to a considerably lesser extent, a global level. On the other hand, the museum is clearly nation-based: its dominating perspective is of a Poland caught between the two totalitarian aggressors of Germany and the slightly less extreme Soviet Union. ${ }^{19}$ The majority

19 See also Siddi and Gaweda 2019, 264. The first section of the permanent exhibitions also features rooms on fascist Italy and Imperial Japan, however since these totalitarian systems do not affect the Polish story, they remain a by-product of the exhibition concept. 
of its museum objects and sources are Polish, which is especially notable in general galleries such as that on Forced Labor. ${ }^{20}$ It is important to note that the national perspective - in the original exhibition - is anti-heroic and based mostly on collective suffering, particularly that of civilians. This combination leads to an exhibition that simultaneously relies on master narratives; creates a secondary experientiality that simulates structures of resistance, suffering and violence; and expresses transnational constellations that create questions of whether and how experiences are nation- and group-based, or universal. At the same time, the MIIWŚ is able to employ new angles on the story level that have not yet been displayed or highlighted in Polish or other European museums. The museum's master narrative substructure prevents the exhibition from being as open-ended in meaning as, for example, the MHM. There is a clear message concerning the origins of violence: who caused it, who suffered from it (including German and Soviet civilians), and the fact that war and violence create universal suffering.

The visitor enters the permanent exhibition located 3 floors underground and first reads an approximately 1000-word introductory text entitled "The Greatest Catastrophe in History." Its text contains all the elements that make up the museum. It highlights the human cost and locates the cause for the catastrophe in "the totalitarian regimes of Germany and the Soviet Union.” The text goes back and forth between a universal approach outlining how "people paid the highest price for defiance," and highlighting the story of Poland "who found itself in the eye of the storm." Without attribution to any one group, the text concludes by reinforcing the values of freedom, dignity, life, and sacrifice, ${ }^{21}$ which together with violence, total war, ${ }^{22}$ and suffering form the abstract concepts reinforced throughout the museum. This creates a kind of secondary expe-

20 The transnational parts of the Forced Labor section are exclusively expressed through photographs in slide shows. The MIIWŚ has a complex way of acknowledging the Shoah and the suffering of Jews. For example, aside from the survey panel, Jews or Polish Jews are not explicitly mentioned in section 8.5 on concentration camps. The complex balance of exhibiting the suffering of Jews and of Poles in the museum will further be discussed in chapter 7 below.

21 "Now, just as then, freedom, dignity and life, for which millions of people made sacrifices in 1939-1945, are universal values."

22 Former director Machcewicz points out that the museum uses the term 'war of annihilation' instead 'total war,' because the latter is shaped too much by Nazi ideology (2019 [2017], 79-80). Yet this choice demonstrates a clear agency of the aggressor countries, whereas 'total war' as it is used in Mémorial de Caen or in the House of European History for instance allows for a more open forum for comparing suffering in an anthropological form. The MIIWŚ never allows the visitor to forget about historically established agency and consequently, in most sections, it cannot diversify its framework of agency. 
rientiality. The visitor then enters section A, "The Road to War," which is comprised of a semicircular, darkened film theater. The introductory film exemplifies the ways in which visitors are drawn into a two-fold narrative, which focuses, on the one hand, on the Polish perspective and, on the other, on a transnational humanist perspective. The film starts with the fragility of the order established through the Treaty of Versailles, the threats placed on democracy, and the drive for expansion as Italian Fascism, Soviet Communism, German Nazism, and Japanese Imperialism threaten newly sovereign countries such as Poland. Whereas the traditional storyline in most European museums views the Treaty of Versailles as the first, or at least an important, step in the development of another world war, the film in this theater provides the prologue to the exhibition's two main arguments. On the one hand, the film shows the world collapsing under the impact of new war technology on soldiers and civilians. On the other hand, the Treaty of Versailles is viewed as a positive force. First, the museum notes that US President Woodrow Wilson adopted the idea of giving people the right to self-determination, which fostered independent nation states. After the end of the First World War, the formation of the Second Polish Republic (and other new states in Central and Eastern Europe) is foregrounded and consequently the treaty is represented largely in a positive light, as a creator of independent nation states: "Poland regained her freedom after over a century of Partitions.” The MIIWŚ clearly recognizes frictions between neighboring states. Thus, national independence is not narrated with pathos, but described in a factual way by providing a sequence of historical events.

However, the exhibition also emotionalizes its message. This can be seen in its representation of the Russian threat, in which images are used to emotionally support the narrative message and emotionally supplement the text's factual tone, reinforcing a specific master narrative and Polish national cultural memory (see also Logemann and Tomann 2019). The visitor first sees an agitated Lenin preaching revolution after Russia did not participate in the Versailles Peace talks. The narrator then notes that the Soviets wanted to spread the Revolution to the West, accompanied by images depicting a large group of fighters charging forward with their spears out. The narrator continues: "This plan failed when their Red Army was defeated by the Poles outside Warsaw in 1920. The young Polish state defended its independence." The Polish victory is shown through footage of machine gun fire and airplanes, highlighting Polish technological advancement and civilization versus the archaic Russian troops. The film ends with the looming threat faced by the newly independent Poland from its two largest neighbors, Germany and Soviet Russia, who "dreamed of revenge and the destruction of the Versailles order." The end of the film highlights the dangers of totalitarianism as they unfold in the following sections of the museum, with sep- 
arate rooms on Italy, the Soviet Union, Germany, and Imperial Japan: "Over Europe loomed the spectre of the next conflict." In summary, the opening film is indicative of the overall museum; it creates perspectives that express the values of Polish resistance, the Polish fight for freedom and survival against two enemies who are fully responsible for the war. It does so while highlighting a system of universal human values.

The MIIWŚ conceptualizes totalitarian societies by employing a predominantly documentary, descriptive style. ${ }^{23}$ The visitor learns how totalitarian systems emerged in different societies, especially by example of the Soviet Union and Germany. Emotional displays mainly use the propaganda techniques that the totalitarian systems themselves employed. This is found, for example, in a display in the subsection of the room "Nazism in Germany: Dispensing with Morality for the Sake of Race” entitled "The Master Race and Subhumans," in which numerous pages of a coffee-table book displaying images of 'ideal' beauty are contrasted with propaganda photographs of the mentally ill. ${ }^{24}$ Nearby, an electronic book that automatically cycles through its pages also emotionalizes the visitor to the effects of book burnings, when a photograph of a book burning in Berlin turns into pages from books by Erich Kästner and Kurt Tucholsky displayed in burning flames. Tucholsky's Das Lächeln der Mona Lisa ("Mona Lisa's Smile") appears in burning red and orange: the visitor can almost empathize with the material object whose destruction is being simulated here.

Similar to the German museums analyzed in this study, the Bastogne War Museum, and the Imperial War Museum North, the MIIWŚ uses documentary techniques that establish historical facts for the visitor. However, these facts are always placed within the narrative framework of totalitarianism creating human suffering in total war, which furthermore identifies Poles as victims with minor exceptions. In one way or another, Poland (and to a lesser extent other nations in Central Eastern Europe) sits in-between totalitarian powers. This is also evident in the experiential installation depicting a main street in Poland in the 1920s after the rooms about Soviet, Italian, and German totalitarianism, and before the one about Japanese totalitarianism. The emotional message of the street locates peaceful, regular life between all the oppressive developments around it: the Polish people seem to dream of traveling as one shop window demonstrates, rather than of war and dominating other groups and nations.

23 Puttkamer $(2017,5)$ notes that the concept of the totalitarian is not problematized, but introduced as a set value.

24 See Heinemann 2017, 477-479, for a criticism of the lack of contextualization of graphic images in the MIIWŚ. 
Consequently, open documentation without interpretative message is - with some exceptions ${ }^{25}$ - a less important method for the museum.

The exhibition always represents texts, images, and objects within the double narrative framework identified above. This master narrative structure becomes symbolically evident in two installation rooms early in the exhibition. ${ }^{26}$ The last room of the section "Peace at any Price? Ideological Questions and the Collapse of the Versailles Order in Europe" features one of the most prominent symbolic displays in the museum. As the visitor leaves the area on pre-war Gdańsk, they first see an enlarged portrait of Polish Foreign Minister Józef Beck giving a speech to the Sejm, the lower chamber of the Polish parliament. Audio plays continuously, featuring parts of the speech in which Beck proclaims that Poland will not allow anyone to cut it off from the Baltic Sea against German demands. The text panel accompanying this display ends on the motif of Polish resistance: "This was the first time that the Third Reich's drive to expand encountered resistance [...]." Following this, the visitor sees facsimiles of the secret protocol of the Molotov-Ribbentrop Pact from August 23, 1939 and then walks through a narrow hallway, in which three large swastika banners are displayed to the left and nine large rectangular Soviet flags to the right (see fig. 23). On the one hand, this establishes an emotional bond between Poland in its double role as both victim of two totalitarian powers and as first resister fighting for freedom. Like threatened and resisting Poland, the visitor must also walk between the menacing symbols of the two totalitarian regimes. The visitor is dwarfed by the two large installations and placed in the position to empathize with the Polish role of being caught in the middle. ${ }^{27}$ On the other hand, however, it is important to understand that the MIIWS - unlike the House of Terror in Budapest or the Warsaw Rising Museum - also allows the visitor considerably room for distantiation and reflection in its other rooms. Or, to put it differently, and as will be seen below, it does not fabricate a claim of factuality as seen in Warsaw - at least not in the original exhibition.

25 For example, the original film in the final exhibition rooms and the stories of post-war expulsion and migration are fairly open, see below.

26 When Machcewicz (2019 [2017], 90 - 91) argues that his museum follows a forum strategy, whereas the new leadership aims for a temple museum, one should consider that the original exhibition also closes off certain interpretive possibilities. In other sections, especially the transnational ones, it can clearly generate debate and more open-ended interpretations.

27 The new film in the last room of the permanent exhibition plays on this metaphor by showing two walls apparently crushing the Polish resister in the middle, before the Polish underground state miraculously appears to demonstrate continued Polish resistance (see below for further details). 


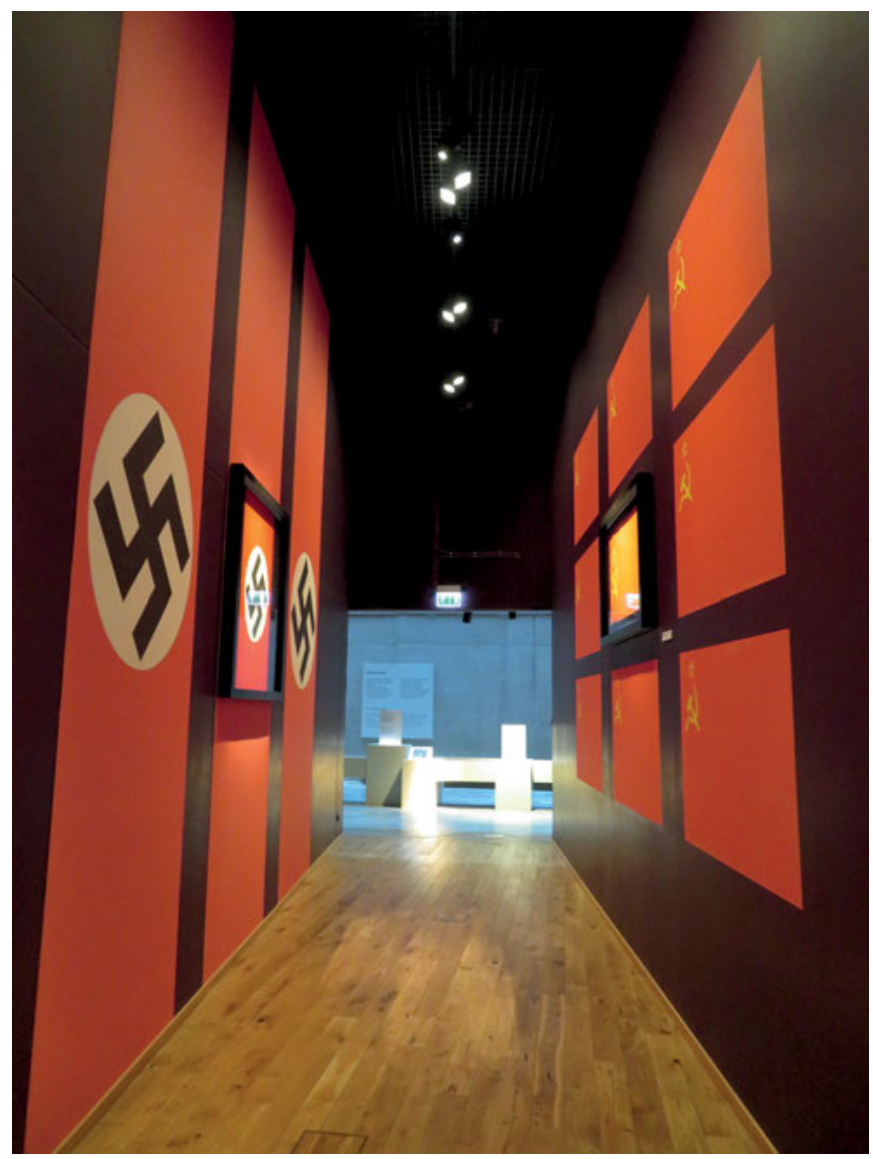

Fig. 23 Corridor between Nazi Swastikas and Soviet Hammer and Sickle Flags. Permanent Exhibition. Muzeum II Wojny Światowej (Museum of the Second World War), Gdańsk (Photo: Author, 2018).

Wartime atrocities originate in the war's first phase, particularly during the Polish campaign and occupation. For example, in the museum's third section, "War after All," the visitor is confronted with the immediate crimes of the German Einsatzgruppen, early in the war, following actions of the Wehrmacht against Polish civilians and the Polish elite: this is done through a scenic installation of suitcases, large poster-photographs, and filmic evidence displayed on a small screen. It speaks to the museum's reflectedness that it also reflects on possible Polish atrocities when it displays a film on the so-called 'Bloody Sunday,' in which German civilians were killed in Bydgoszcz, reflecting on the construction of propaganda and history from both sides. The next room symbolizes the begin- 
ning of 'total' warfare in Poland. ${ }^{28}$ Two rooms later, the visitor encounters the siege of Warsaw in a small cinema, playing an original film by Julien Bryan as it was broadcasted to the USA in 1940. Outside of the cinema, the enlarged photographs of two children are shown, among them the iconic picture of the 10year-old Kazimiera Mika crying over the dead body of her older sister Anna. ${ }^{29}$ The short sequence of photographs underneath also depicts, among other things, a photograph of the filmmaker consoling the girl. As exemplified in the Julien Bryan room, the museum establishes a reality of war crimes by creating a strong affective impact on the visitor. This feeds both the museum's master narrative of the totalitarian onslaught against Polish freedom, and its message of universal suffering borne by civilians in total war. The exhibition never loses sight of its master narrative and the historical structure that total warfare was caused by the German and Soviet totalitarian regimes. This holds true for events such as the Air War, German and Soviet massacres of civilians, forced deportations of Polish and other people, flight and expulsion, and post-war deportations.

The museum's master narrative also counterbalances the Western narrative and its focus on specific events and turning points during the war in numerous ways. The museum makers have highlighted this as major justification of the museum's existence: many museums downplay the early phases of the war, so that the core of the Western narrative either focuses on the German war against the Soviet Union or on allied efforts (see also Heinemann 2017, 467). The campaign against Poland and its subsequent occupation is more often than not a mere footnote. The original exhibition of MIIWŚ mentions well-known heroic stories - from the defenses of Westerplatte, the Gdańsk post office and the Hel peninsula, to intelligence efforts in informing the Allies about the crimes in Auschwitz and the development of V1 and V2 rockets, to the success of Polish soldiers at Monte Casino and other Allied campaigns. In doing so, however, it avoids taking a heroic or emphatic tone. Instead, its master narrative works toward underscoring universal values such as freedom, dignity, and life, while allowing for a transnational comparative framework. It is significant that Polish perpetration can be mentioned at all: examples of which include the 'Bloody Sunday' display (mentioned above); the Polish state profiting from the Munich agreement by demanding and receiving the region of Zaolzie from Czechoslovakia; the pogrom in Jedwabne; and minor instances of collaboration with the Germans under occu-

28 For details see chapter 8 and the "Prologue."

29 The same image without contextualization is displayed in the Canadian War Museum and as part of a film in the New Orleans WWII Museum. 
pation. However, all cases of Polish perpetration are clearly marked as being caused by German or Soviet totalitarianism, so that they do not affect the overall master narrative. ${ }^{30}$ Themes such as antisemitism in Poland and Polish perpetration hardly appear in the museum. ${ }^{31}$ Even the few examples of Polish perpetration depicted strengthen the museum's clearly assigned concepts of right and wrong.

In addition to the Polish narrative, the concept of total war is the second thematic anchor of the exhibition. The MIIWS highlights the suffering of civilians, the destruction of public space, genocide, ethnic cleansing, pogroms, and effects of occupation, resistance, and collaboration throughout the museum. It provides clear arguments that fit its totalitarian master narrative to explain later atrocities. For example, the museum underscores that pogroms against Jews or the ethnic cleansings perpetrated by Ukrainians and Croatians were inspired by the genocides of the Nazi regime. What distinguishes the MIIWŚ is its explicit transnational sections; for instance, the air-war section highlights raids on Spanish, Polish, Dutch, British, Finnish, Yugoslavian, Philippine, and Japanese populations. ${ }^{32}$ Former museum researchers and curators Anna Muller and Daniel Logemann highlight the potential the museum offers the visitor to draw conclusions about the mechanisms of violence and racism:

The museum invites visitors to view and ponder various moments and aspects of war; its intent is not to commemorate the death of the innocent and heroic but to understand the scope and consequences of rabid nationalism, racism, and intolerance. The goal should be to settle or challenge established meanings through dialogue at the intersections of many other discussions: about human nature, national histories, and mechanisms of violence and exclusion. (2017, 92)

The main technique of the museum is to achieve such a dialogue through parallel constellations. Indeed, it creates a unique global memory through the integration of global themes. For this global memory effect, it is relevant that - even if it is only evident in three fairly brief sections - it also mentions Imperial Japan's acts of perpetration and the suffering it has caused. The exhibition also features multimedia computer stations with simulations of maps, and brief chronological

30 The memory debates and the success of the PiS (the governing Law and Justice Party) also indicate that the majority of Polish people would not accept a stronger focus on perpetration, so that - as seen from the memory debates in the USA and Canada - too daring of an approach would challenge the overall structure of the exhibition.

31 For the tension between perpetration and victimhood in the Polish memory discourse see also Kurkowska-Budzan 2006, 135.

32 See also chapter 8. 
captions depicting all of the war's global theaters. The global structure of the museum allows for rooms on civilian suffering in the Soviet Union, such as in those on prisoners of war, which strongly emphasize the experiences of POWs, ${ }^{33}$ and in the room featuring the Siege of Leningrad in the section "Merciless War: Criminal Methods of Conducting War."

On the one hand, the museum's transnational approach means that the visitor can compare similar themes across different nation-states, such as totalitarianism, the suffering during air wars, hunger, collaboration, resistance, terror, ethnic cleansing, and the suffering caused by expulsions and resettlements from numerous countries. The analytical question emerging from this approach is whether it challenges visitors to find differences and variations in violence, or whether the simultaneities between different countries simply flatten different historical experiences toward an overarching and universal message. On the other hand, the exhibition creates simultaneities between different topics of perpetration and suffering. This allows the visitor to reflect on how cultures of violence emerge and what effects they have on numerous victim groups within the framework of total war, with a particular emphasis on the suffering of civilians (see also Muller and Logemann 2017, 92-93).

The most prominent transnational section in the exhibition is section $\mathrm{B}$, entitled "Everyday Life during the War and Occupation: The Biggest Front of the Second World War." This section is arranged in two aisles, with its major part located in the museum's main hallway, which the visitor constantly traverses when going back and forth between the first seven sections. The visitor encounters the final section upon leaving section 9 on the Holocaust and crossing into section 10, "Ethnic Cleansing" and 11 "Resistance." Section B is exclusively based on objects in display cases and tables located in the middle of the hallway, along with integrated monitors displaying historical photographs and brief introductory texts explaining subsections such as food rationing, travel, dress and fashion, love, information, music, work, play, and children. It is also clear that in one way or another, these fields affect all of the occupied nation-states. The visitor is given no opportunity to understand the historical specificities regarding the similarities or differences between conditions in different occupied countries. This section also does not allow the visitor to empathize with concrete individual perspectives. Instead, the strength of the section is to trigger the visitor's imagination and empathy for the universal human condition during wartime occupation.

33 Heinemann 2017, 464, points out how depicting new victim groups in the war that were before almost unknown in Poland and in many other countries, breaks new ground. 
Unlike the "Everyday Life during the War and Occupation" section, the first room of the seventh section on the German occupation of Europe, "Occupation and Collaboration: German, Soviet and Japanese Systems of Occupation,” is very dynamic, in allowing the visitor to compare the situations in different occupied nation-states. Visitors can identify both universal and nation-specific elements in human behavior under occupation. This section discusses the German policies in the occupied territories and the forms and causes of collaboration. In order to do so, it uses a blend of survey texts, display cases, computer stations with slideshows combining texts and photographs; quotations in large letters; enlarged photographs and announcements; and propaganda posters. ${ }^{34}$ The slideshows help the visitor understand different dimensions of occupation. Though this section does not challenge the general assumption that there is good victimhood and bad totalitarian regimes, the visitor receives a varied picture of conditions under occupation and of distinct National Socialist policies. In this way, visitors are enabled to draw their own conclusions about how specific actions and attitudes during occupation should be assessed. This is most evident in the section on collaboration. The exhibition gives a differentiated picture of various types of collaboration and explains possible motivations behind the decision to collaborate. The visitor can decide how to evaluate the different examples and forms of collaboration. Is it different if an existing police force collaborates with the occupier? How important is it that collaboration is voluntary? Can one demand that everybody support the resistance? Because the MIIWŚ foregoes a moral assessment, the visitor can develop questions from these exhibits. Since visitors first learn about the various occupation policies in different countries, they can judge whether informing on and denouncing other people is the same in all occupied countries, or whether there are explicit differences on a case-bycase basis.

Because the set-up of the room is fairly open, it creates interpretational opportunities for the visitor. For example, in the section on Polish occupation, the visitor finds a quotation, written in large letters, on the Polish population from Colonel Claus von Stauffenberg: "This population is an unbelievable rabble; there are so many Jews and mixed-bloods. It's a population that only feels well under the whip.” The quotation serves as an illustration of German attitudes toward Poland during occupation. Furthermore, an informed visitor can contrast this with any lionization of Stauffenberg regarding the July 1944 assassination attempt on Hitler. Another quotation, this time from French Prime Minister Pierre

34 This section creates dynamic constellations with the resistance section later in the exhibition. 
Laval in 1942 reads: "I wish for a German victory because, without it, Bolshevism will establish iteself [sic] everywhere. France must not remain passive or indifferent to the enormous sacrifices the Germans are prepared to make to create a Europe in which we must occupy the place we deserve." Whereas visitors know, in light of all the Germans crimes presented throughout the museum, that such an opinion is factually wrong, they can consider whether such a conviction could justify collaboration. The visitor also learns that France had very different occupation conditions to those of Poland, which could explain or at least rationalize the quotation. The transnational approach in the "Occupation and Collaboration" section allows the museum to express elements of universal memory within a historically specific context, while maintaining some historical specificity on the national level. The MIIWŚ exhibits a relatively clear historical framework, Polish cultural memory, and master narrative; however, it also succeeds in diversifying historical arguments without flattening historical specificity, similar to the MHM.

Section 11 is introduced by the sculpture-like presentation of the word "OPÓR" (resistance), which creates an immediate connection to the word "TERROR" that welcomes the visitor to sections 9 and 10 on German and Soviet terror and on the Holocaust. Terror and resistance are thus the conceptual dichotomy anchoring the whole museum. The resistance section is divided into five sub-sections. The first sub-section documents the roles of individual resisters from different countries and commemorates their actions; the second informs the visitor about the Polish Underground state in an experiential setting; the third - mimicking an interior room of a house - is a transnational display of civilian resistance in Europe; the fourth documents the struggles of partisans and other underground operations across multiple nations; the fifth is divided into two parts and charts various uprisings against the Nazi state. Above the entire section, large screens with historical footage and photographs depict life under German occupation above ground. The extremely high ceilings make this installation quite effective. Visitors are put into a situation where they empathize with one specific side, the underground and resistance. This works in particular for the Polish underground state, civilian resistance, and uprisings. A more detailed look at the civilian resistance room demonstrates a new effect created by the museum's transnational approach. The visitor steps onto a floor littered with resistance flyers, caricatures, and symbols. Different sections of the room highlight civil resistance as the power of community, of the individual, and of laughter as well as listening to the BBC as act of resistance. Resistance in seven countries is represented, all of which, except for Czechoslovakia, are located in Western 
Europe. ${ }^{35}$ Unlike in the occupation-collaboration section, the visitor does not obtain a picture of the varying conditions surrounding resistance. Additionally, the objective of the display does not seem to be the simple expression of universal conditions of war. Here, the transnational approach makes an emphatic statement about the possibility and effectiveness of resistance in conditions of wartime occupation. The focus is not on German punishment, which can be found in other sections about terror, war crimes, and the Holocaust. However, visitors might ask themselves how they would have acted in similar situations and whether they would have dared to defy the oppressor. While the room also represents facts on civilian resistance in many countries, the overriding transnational message professes overarching support for such resistance. This has the power to shape and confirm the cultural memory of the nations represented. An affective representational mode dominates over a cognitive one, and consequently, the floor made up of resistance posters and the sound of BBC broadcast experientially unify visitors. ${ }^{36}$

The part of the museum on uprisings is even more effective regarding the emotional staging of transnational memory. However, this exhibit seems to be bypassed or hardly noticed by many visitors, since it takes considerable time to immerse oneself in the presentation and there is limited space for visitors to linger (see also also Heinemann 2017, 468). The transnational display integrates the uprisings in the Warsaw Ghetto, Warsaw, Paris, Slovakia, and Prague. Only the one in Paris was successful; the Prague Uprising is represented as successful, but ending in disappointment, as the Red Army freed the city and not the Americans. The introductory text highlights the motives behind these insurgencies - national freedom, patriotism, and vengeance. ${ }^{37}$ Visitors can easily miss the lengthy slideshow display to the right of the entrance, which includes data, photographs, captions, factual events, and statistics concerning all five uprisings. ${ }^{38}$ The presentation remains, for the most part, neutral and factual. Indeed, the most interesting element is that data from the various uprisings is summar-

35 The "London Calling" display also integrates illegally listening to the BBC in Germany and Poland.

36 Machcewicz highlights the intention to create transnational constellations of simultaneously depicted countries, (2019 [2017], 85) without reflecting upon the emotional strategies and effects deployed by the museum.

37 The Warsaw Ghetto Uprising does not seem to be part of the general description. Nevertheless, it serves as a contrast to the other four uprisings, fulfilling an important function in highlighting their conceptual differences.

38 The Warsaw Ghetto Uprising and the Warsaw Uprising are represented with considerably more slides than the other three uprisings. 
ized on-screen, allowing the visitor to draw comparisons between them; this incorporates data regarding opposing forces, the length of the different uprisings, their end results, and the losses sustained on both sides, including insurgents, soldiers, and civilians. Theoretically, this allows for fascinating comparisons to be drawn between the different uprisings. It shows, for example, that the Paris Uprising had greater numbers and support due to Allied pressure, in contrast to the Warsaw Uprising, which is factually demonstrated to have lacked support from Stalin and the Russians. These numbers also elucidate the staggering losses suffered during the Warsaw Ghetto Uprising and the differences in civilian casualties between all five uprisings. It takes about twenty-four minutes for all five slideshows to run: most visitors I observed over eight days of analysis did not take the time to watch even one slideshow all the way through, if they noticed the screen at all. However, this remains an excellent example of how a documentary and open transnational presentation can trigger comparative thought. It is left to the visitors to draw conclusions from this factual representation as to the need for the uprisings.

Following the slideshow, the visitor walks through a narrow corridor into a fairly dark space surrounded by fragmented brick walls. Eight wooden boxes, with five functioning as seats and three as display cases, further the impression that one has entered a provisional space. On the right-hand brick wall, film footage and historical photographs (presented in slow-motion) of the five uprisings are shown on a circular loop on two screens, with a running time of approximately thirteen minutes, supplemented by audio recordings of the voices of insurgents and other witnesses. Both screens are modeled to look like small garage doors and reflect back onto the floor in the dark scenery, further disorienting the visitor. The film reduces any documentary distance and instead further creates an empathetic setting for the visitor. The Warsaw Uprising film moves from a justification of the Uprising and the early onset of euphoria stemming from freedom and a new cultural life, to unease when the Soviets abandon their artillery shelling. ${ }^{39}$ Afterwards, the film shifts to German crimes, the recital of a prayer, and a reflection upon the Uprising's civilian cost: even for those who do not fight, death appears to be everywhere. Clearly, the idea here is to allow the visitor to empathize with the thoughts of insurgents, for example through the use of phrases such as: "I felt that since I was alive I had a right to fight"; or, when one sees the stern face of a Soviet soldier and Stalin in a split screen with the

39 Heinemann $(2017,470)$ has pointed out that the Warsaw Rising Museum and the MIIWŚ display similar contents, but use very different narrative trajectories. The former depicts the absolute necessity of the Uprising, the latter highlights the total destruction and devastation that it wrought. 
text: "They stayed there and watched us die." The final part of the film expresses total agony and despair: "This is hope dying. The Uprising at the agonal stage." The right screen depicts mothers holding their children and then ruins with wooden crosses appear on the left screen with the caption "Behind us Warsaw, all our past and all are [sic] hopes buried in the ruins.” The camera then pans to a destroyed Warsaw, and the text states the core sentence also seen in the Warsaw Rising Museum: "We wanted to be free and owe this freedom to ourselves." On the left, footage shows one man hobbling through a total wasteland.

The message is clearly mournful and depicts a feeling of tragedy; neither the idea of the rising nor its failure is represented as heroic. However, the visitor is led to empathize with the perspective of the insurgents and their perception of the Uprising. Somewhere on the border between primary and secondary experientiality, the MIIWŚ simulates a collective perspective of how insurgents could have felt in different situations, in a similar fashion to the Imperial War Museum North. The distance between the visitor and the historic perspectives is so strongly reduced that an analysis of the necessity of specific uprisings is impossible: the visitor relies on the hopes and motives of the insurgents. The montage of the five uprisings in the film presentation and its scenic setting allows for secondary experientiality, since the visitor can understand the possible motives, hopes, and desires of various uprisings, and whether or not they had a chance to succeed. Here, universal concepts such as freedom, dignity, life, and sacrifice, emphasized in the opening panel of the exhibition, emerge as structural concepts staged in the museum. At the same time, the visitor receives no tools to conduct a historiographical analysis about whether a given uprising made sense from a strategic or political perspective. The museum stages national and transnational cultural memories, which the visitor could interpret as historical truth. This section presents the emotional message that under totalitarian occupation, resistance and uprisings always make sense from an emotional and moral point of view. The representations are based on individual memories that have become collective, which is reinforced throughout the exhibition.

To understand this further, it is useful to take a closer look at the brick wall representation of the Warsaw Ghetto Rising. Here, the MIIWŚ mixes a number of voices: some are named as Jewish insurgents and ghetto inhabitants, while others are Polish voices outside the Ghetto walls (see also Heinemann 2017, 469). On the one hand, the visitor is led to understand why resistance and uprisings make sense, even if there is no chance for an uprising to succeed: Icchak Cukierman is quoted as follows: "For our time has come, without hope and with no chance of rescue"; Mordechaj Anielewicz notes that Jewish self-defense "has become a fact" and speaks of the "magnificent heroic struggle of the Jewish fighters"; Marek Edelman reports that it was satisfying to see the Germans show fear. It 
is then made clear to the visitor how the Germans thrashed the Uprising with gas grenades. The utter destruction they wrought is consistently counterbalanced with the Polish will to resist. The final voice in the recording belongs to Adina Blady Szwajger, who worked in the children's hospital in the Warsaw Ghetto, and highlights the total loss of life and witnesses: "But there is not a single fragment of the wall that separated one third of the city from the rest. There is not a single burnt-out house from the windows of which mothers had thrown their children before jumping out themselves." While this audio plays, the viewer sees images of the completely destroyed ghetto, void of life. The transition to voices outside of the ghetto also highlights the isolation faced by ghetto inhabitants during the Uprising.

The visitor can empathize collectively with both the Jewish people inside the ghetto and the Polish people outside of its walls. The film simulates the devastating loss of hope as well as the symbolic significance behind the Warsaw Ghetto Uprising. Naturally, the visitor cannot empathize directly with somebody experiencing certain death in the hopeless situation within the ghetto, but these installations simulate collective gazes that allow for a structural experience of these uprisings and their motives, hopes, successes, and failures. The transnational memory approach taken here allows the museum to bring the concrete and constructed collective perspectives of each historical event to a meta-level. This, in turn, lets the visitor emotionally experience the different motives behind the uprisings that are shown. This is only possible on a secondary level: in other words, the transnational approach of the MIIWS prevents the museum from falling into the trap of suggesting that the primary feelings of insurgents can be reexperienced. But visitors are put into a position to emotionally understand the drive behind the uprisings and why they might be emotionally and symbolically relevant beyond any pragmatic, functional, or strategic reason.

My final example of transnational constellations in this museum relates to flight and expulsion (Mikuska-Tinman and Jaeger 2020). The second room in the sixteenth section "The War is Over" is entitled "Fall of the "Thousand-Year Reich': German Crimes and Population Flights.” Here, death marches from concentration camps, the flight from East Prussia and the sinking of the Wilhelm Gustloff, and rapes perpetrated by the Red Army work as one cluster. The room displays the bell of the Wilhelm Gustloff and provides encyclopedic information on the flight of Germans from East Prussia, using a slideshow to depict the fate of German passenger ships and Russian massacres in the region. Death marches and the plight of Polish or Polish-Jewish women dominate the room's displays. For example, an artistically animated, intentionally blurry narrative video is used to tell the story of a woman who escapes from SS guards, while they shoot at her and her sister as they flee over a frozen lake. A similar comput- 
er animation, paired with the voice of a German woman living in Gdańsk who was raped by the Russians, underscores the fact that Germans suffered too. The visitor has, at this point, been exposed to German atrocities and terror in occupied Poland and the Soviet Union in previous parts of the exhibition. Here, the MIIWŚ introduces a very original transnational frame, which both includes the suffering of groups from perpetrator nations and gives individual suffering a voice. One can ask oneself the unanswered question of what German or Soviet suffering means in relation to the suffering of others: from a human point of view, is the suffering of people from perpetrator nations comparable to the one of victim groups? Or, given that the museum maintains a narrative framework that depicts all violence as originating from the policies of totalitarian regimes, is there a difference? The MIIWS provides a twofold answer to these questions; on the one hand, the answer lies in the master narrative as discussed: namely, that this German suffering is self-inflicted. On the other hand, the museum expresses a perception of universal suffering that allows for a more open comparison.

This interpretation becomes even clearer in the following section "After the War," with the sub-section "Great Transformation: Migrations and Borders - the Great Powers Assigned Many New Borders.” Here, the museum integrates the post-war expulsion of Germans with a wider framework of Central and Eastern European expulsions and population movements. The combination of objectbased and experiential narratives through photographs, objects, video interviews, and atmospheric settings, allows some room for interpretation. This section creates a secondary abstract reality in the way in which the collective impact of expulsion on the human being, independent of group identity, can be expressed. This room's design is identical to an earlier room in the section "Terror," entitled "Resettlements, Deportations, Expulsions: Hitler's and Stalin's Social Engineering," with a floor map charting migratory movements and thematic huts symbolizing the homes that people left behind. Therefore, it is once again situated in a clear historical-causal context, which also supports the museum's master narrative structure that assigns concepts of right and wrong.

Nevertheless, this transnational approach allows the visitor to leave the national framework behind and to consider different conditions of hardship. The room itself showcases this transnational technique, displaying three victim groups and their stories in separate huts: Poles who were repatriated from formerly Polish, now Soviet territories in the East, to formerly German, now Polish territories in the West; German post-war expellees from Poland, Czechoslovakia, and Hungary; and Baltic and Ukrainian expellees who had to leave their home and resettle in other parts of the Soviet Union. Visitors are led to simultaneously experience the loss of home and hardship during moments of departure and 
travel, without losing sight of the historical contexts that led to these population movements (Mikuska-Tinman and Jaeger 2020). Objects allow visitors to reflect upon the comparability between different acts of social ostracization on ethnic grounds and different contexts for the emergence of violence. For example, a badge and armband that Germans were forced to wear during the expulsion mirrors the German treatment of the Jews and other concentration camp inmates (Mikuska-Tinman and Jaeger 2020).

The MIIWŚ is clearly able to maintain its historical specificity, while also creating and simulating structures that overcome historical patterns and preconceived narratives: this allows for various forms of experientiality. The dynamic and provoking challenge for visitors is to reflect upon whether, for example, the aforementioned story of the death marches is comparable to that depicting the rape of German women. This provides the opportunity for a dynamic reflection of memory. The historical framework pertaining to how Germans brought suffering on themselves is presented, as is an examination of the human impact of suffering and atrocities. Although the historical framework of the MIIWŚ is closed, ${ }^{40}$ its transnational techniques create continuous openness and challenges for the visitor. Indeed, these techniques act as a form of multidirectional memory, which allow the visitor to consider and compare different agents and victims within a certain thematic framework. This especially occurs in the installations that avoid the universalization of national experiences and instead place historically and nationally specific perspectives in tension with transnational and secondary anthropological insights. In this way, one can see the productive effect of this transnational approach.

The largest case of intrusion by the new museum leadership in the original exhibition can also be seen as a warning of how easily the dynamics of the MIIWŚ can be overwritten. In its original version, the viewer had already walked through a Polish street in ruins directly at war's end, indexing the destruction to the reconstructed street they had seen in the second section. They then encountered a film installation as the final part of the museum, where two screens were split by an iron curtain, showing iconic photographs of historical events that occurred post-1945. ${ }^{41}$ Here, the museum connected past and present. ${ }^{42}$ When the

40 With the exception of the original final film, discussed in the next paragraph.

41 David Clarke and Paweł Duber $(2018,7)$ also discuss how the film implements a version of Polish memory "that attempts to acknowledge both heroism and less admirable episodes in the nation's past." They point to the example that the film "shows the anti-Zionist campaign launched by the communist government of Poland in 1968, which led to 13,000 Polish Jews (around half of the remaining population) applying to emigrate to Israel.” 
events depicted in the film reached the twenty-first century, the two screens merged $^{43}$ and showed the destruction of today's Syria, indirectly asking the visitor the question: Why is this destruction, this human suffering reoccurring? Whether this contemporary conflict has similar origins to the totalitarian ambitions and policies of the Second World War remained open. However, this was one of the first changes made by the new government-endorsed museum administration in October 2017. The new film The Unconquered is a fast-moving film, rhetorically efficient and highly manipulative in steering the visitor toward a singular emotional response. In order to do so, the film uses the style of a videogame to tell the story of a Poland that, attacked from two sides, resisted and survived two dictatorships. It displays two identical screens, the one on the left providing English subtitles. A narrator full of pathos, accompanied by a dramatic musical score, tells the story in such a way that nobody can miss the symbolic meaning of the film's images. Its heroic tone, with particular emphasis on military success, does not fit to the rest of the exhibition. Instead, it indicates the lack of interest from the new museum leadership in maintaining the transnational theme or tension that allows the museum to create secondary experientiality. There seems to be no open-ended questions or space for critical analysis for visitors or researchers. The only task would be to find further evidence to support the master narrative of an unconquered Poland full of valor. ${ }^{44}$ History is seen exclusively in black-and-white. All Polish people have become a single collective and experientiality is reduced to an emphatic ideological framework. ${ }^{45}$

42 See also Machcewicz (2019 [2017], 81-82), who describes how the museum planners changed from an optimistic European end to an ending that integrated images of the conflicts in Ukraine and Syria and of the European migrant crisis.

43 A previous scene shows two identical screens of Steve Jobs presenting the Apple iPhone 3G to the global public in 2008, combining East and West in modern technology and capitalism. 44 It seems only logical that the new still-to-be-built branch of the MIIWŚ at the Westerplatte peninsula seems to be planned as an archeological dig for traces of a heroic and matyrological battle of the Polish soldier. This is at least clearly the message of the special exhibition in the MIIWŚ Seven Looks at Westerplatte, as it was presented in a special exhibition in the museum from September 1, 2017 to September 30, 2018. Westerplatte can serve as the historical justification and material evidence of the neo Polish master narrative of a heroic struggle won by an 'unconquered' Poland, since it survived two dictatorships. On September 1, 2019, the MIIWŚ held an official foundation stone laying ceremony for the Museum of Westerplatte and the War of 1939 at the Westerplatte Power Plant building. On site, the museum also (re-)opened an archaeological special exhibition on the same day (https://muzeum1939.pl/en/laying-foundation-stone-mu seum-westerplatte-and-war-1939/2673.html, accessed 13 October 2019).

45 For further analysis of the new movie, see the Holocaust section 7 below. 


\subsection{The House of European History in Brussels}

Up to a certain point, both the German Russian Museum (DRM) and Gdańsk Museum of the Second World War (MIIWŚ) create transnational memories. Both transnational projects are have been restricted through political interests. Both museums create gazes that examine themes and concepts from the perpetrators perspective, including from civilian suffering, flight and expulsion, pogroms, resistance, freedom, and terror. A concrete sense of national reality is mostly maintained in both museums: the DRM reflects contemporary historical knowledge and national cultural memory, while the MIIWŚ comes close to reenacting the political memory battles of today's Poland. Both museums construct collective perspectives, whether they relate to nations, humanity, or specific groups such as prisoners of war or insurgents fighting occupying powers. Transnational concepts, as seen above, are not automatically linked to a closed or open exhibition format. The DRM and the MIIWŚ both use their transnational set-up to open possibilities for interpretation. Constellations emerge and visitors must decide the degree to which these constellations point to comparability or even universality, and whether or to what degree they indicate historically or structurally distinct situations for different national groups and subgroups. Both the DRM and the MIIWŚ have a strong historical basis that is connected to historical events and also - in the case of the MIIWS - a master narrative. This historical basis dominates the abstract and structural secondary experientiality that can be seen in the Topography of Terror and in the Bundeswehr Military History Museum in particular.

How does this transnationalism - which allows for the comparison of multiple group experiences despite a strong historical framework - compare to the presumably ultimate 'transnational' museum that opened in Brussels on May 6, 2017: the House of European History (HEH)? It is located in the completely renovated Eastman Building in Parc Léopold in the 'European district' of Brussels. ${ }^{46}$ The institution, funded by the European Parliament, is governed by a Board of Trustees and an Academic Committee made up of university professors and museum experts. ${ }^{47}$ The museum's mission underlines that the $\mathrm{HEH}$ strives to be a

46 The renovation and contemporary extension of the building was done by Atelier d'architecture Chaix \& Morel et associés (France) JSWD Architekten (Germany) and TPF Engineering (Belgium). See also House of European History 2017b; Blandini 2017.

47 The Board of Trustees is chaired by former President of the European Parliament Hans-Gert Pöttering who initiated the project in his inaugural speech in the European Parliament in 2007. For further data see the info brochure Facts and Figures (House of European History 2017b); see 
dynamic and open transnational museum. Its permanent exhibition covers approximately 4,000 square meters. Though it is not centered on the Second World War as such, the museum makes "the tragedies of the 20th century" (House of European History 2017b) 48 $^{-}$the two world wars, the rise of totalitarianisms, and the Holocaust - the core foundations of the European integration process after 1945. Its mission statement points out the fragility of peace and prosperity: "In times of crisis, it is particularly important to develop and sharpen consciousness of cultural heritage and to remember that peaceful cooperation cannot be taken for granted" (House of European History 2017b). This statement clearly connects an understanding of historical processes to their relevance for the present and future. It also seemingly advocates for debate and openness instead of closure ${ }^{49}$ and for a diversity of memories in Europe. ${ }^{50}$ The HEH asks the crucial question: "Will the House of European History replace national histories?" and emphatically answers that "[t]he House of European History will not be a simple sum of national histories, nor does it seek to replace them. The House of European History will be a reservoir of European memory, containing experiences and interpretations in all their diversity, contrasts and contradictions. Its presentation of history will be complex rather than uniform, more differentiated than homogeneous, critical rather than affirmative, but it will focus on the emergence of the European Community" (House of European History 2017b). In other words, national histories and collective memories are supposed to remain valid, but the HEH seeks to express something 'European' that surpasses any national memory. It is important to note that the concept of collective/cultural memory is extremely prominent in this explanation; at times it seems to completely overshadow history, which is also explicitly expressed by head curator Andrea Mork (2016, 220 -221). The question that the HEH's mission statement circumvents is: Does the exhibition express a linear and progressive master narrative, which automatically leads to European integration? Or is it open enough to display tensions between a European narrative, different nation-

also Vovk van Gaal and Dupont 2012; Kaiser 2017; Mork and Christodoulou 2018. Taja Vovk van Gaal (2018) gives a detailed summary about the genesis of the museum project.

48 See also the website of the museum, https://historia-europa.ep.eu/en/mission-vision, accessed 13 October 2019.

49 "History, which will give citizens an opportunity to reflect on this historical process and on what it means for the present. Parliament believes that the museum can be a place of debate and understanding about contemporary situations from the perspective of their historical roots and in the light of historical experiences" (House of European History 2017b).

$\mathbf{5 0}$ "From the outset, the project has been driven by a desire to promote knowledge of Europe's history and to raise awareness of the diversity of memories within Europe in an open and inspiring fashion" (House of European History 2017b). 
al narratives, and other narratives, so that visitors can draw their own conclusions $?^{51}$ Mork uses the metaphor of a "reservoir of European memory" that contains "experiences and interpretations in all their diversity, contrasts and contradictions" (2016, 221). The former academic project leader and current creative director of the HEH, Taja Vovk van Gaal, and historian-curator Christine Dupont noted in 2012: "The museum is always a 'negotiated reality' [...] and the visitor should be aware of the relativity of the choices. Confrontation with different interpretations of history is also one of the tools that will be used to convey this multifaceted view of European history" (46). However, the promise that the HEH's "presentation of history will be ambivalent rather than homogeneous, critical rather than affirmative" (Mork 2016, 221) can be challenged with a precise analysis of the actual exhibition, which demonstrates how political compromis$\mathrm{es}^{52}$ risk the implementation of an ambitious and dynamic museum project. ${ }^{53}$

51 The question of how European memory and identity can be represented in a museum led to a flood of publications discussing the museum and its political and conceptual genesis before its actual opening (Settele 2015; Hilmar 2016, Kaiser et al. 2014, 114-125, 144-152; Kaiser 2017; Remes 2017), weighing in on the balance between national and European narrative. Weiser - before the opening of the museum - celebrates its potential for "transnational unity" (183) and for entangled memories in a "consciously chosen unity as well as rightful diversity" (2017, 185). Daniel Rosenberg, also without referencing the actual exhibition design, summarizes the project as "a political programme that is more compatible with contemporary challenges facing the continent." He continues that "European integration is thus seen at once as an almost determinist process due to the unified nature of Europe, as well as a complex process due to the diverse and multifaceted nature of Europe" $(2018,33)$.

52 Wolfram Kaiser (2017) has provided a precise analysis of the political pressures on the museum and an analysis of "the changing constellation of actors and networks who have sought to influence" the process of the HEH's creation and the narratives of the history of Europe and European integration. See also Huistra et al. 2014. Anastasia Remes (2017, 114-115) also highlights - shortly before the opening of the HEH - the inherent tension between the multiperspectivity and openness that the curatorial team wanted to implement and the actual implementation of narratives in the exhibition that might be close to traditional national history museums. For the political complexities of the museum's genesis see Borodziej 2018. Włodzimierz Borodziej highlights two particular points of contention: the differences between East and West and that Germany's approach to its national past that is far more self-critical than those of most other countries (37).

53 The early reviews of the permanent exhibitions have been mixed. Krankenhagen (2017) and Kesteloot (2018) have been very positive. The latter even seems to imply that all critical views of the transnational, cosmopolitan approach of the HEH are supporters of a "renationalisation of history" (157). For extremely critical reviews see Lutz 2019, who problematizes the universalization of terror, and Fickers 2018, who emphasizes the HEH's approach to Europe as a problematic history of compromises. 
The permanent exhibition of the HEH is strongly object-based, with large vitrines, a number of multimedia installations, large-screen films, and some experiential settings. ${ }^{54}$ Its core feature is its lack of text or audio throughout the entire exhibition. Instead, the visitor receives a tablet containing all twenty-four official languages of the European Union, giving introductory descriptions of each panel, providing object credits/brief descriptions and audio for the films as well as deciphering the quotations coming from Boris Micka's art installation Vortex of History, which covers five floors in a 25-meter high metal installation. ${ }^{55}$ Individual voices hardly appear in the museum. ${ }^{56}$

The Second World War, the Holocaust, the totalitarian systems that led to the war and their atrocities are central to European memory. Consequently, the war is present throughout the exhibition: first in the introductory section on the second floor entitled "Memory and European Heritage" where the museum introduces fourteen principles that could bind the continent together, such as "State Terror" and "Genocide." 57 Afterwards, on the third floor (see fig. 24), the museum begins European history with the political revolutions of the late eighteenth and nineteenth centuries. It then develops through the Industrial Revolution and colonialism (see also Mork 2016, 227). Europe's cultural memory, clearly paramount to 'history' in the HEH, is shaped by optimism about the progress of civilization in the nineteenth century; yet it comes after the abolition of slavery with "new forms of intolerance and racism," which are particularly evident in the exploitation and 'advancement' of civilization in the colonies. ${ }^{58}$ The museum's narrative uses the idea of the degeneration of humanism to explain the catastrophe of the First World War. This catastrophe allowed for the development of democratic forms of state in Europe following the war. The sub-narrative here is that after the First World War a battle between young democracies and nation-

54 See also the guidebook House of European History 2017a and the edited collection / catalog on the creation of the museum by its staff (Mork and Christodoulou 2018).

55 This results in the strange effect that visitors either are in danger of forgetting about the actual museum space, since reading the tablet becomes paramount, or they perceive the exhibition as strongly object-based and open, since they react sensually to the objects and displays without constantly reading the explanations and captions on the tablet (see also Lutz 2019, 49). In contrast, Krankenhagen $(2017,67)$ follows the HEH design explanations when praising the tablet, but fails to consider the senses and perceptions of visitors in its space.

56 Exceptions only occur in the later parts of the exhibition, such as in the film on the fall of the Berlin Wall or multicultural experiences in today's Europe.

57 The fourteen principles are in order of presentation: philosophy; democracy; rule of law, omnipresence of Christianity; state terror; the slave trade; colonialism; humanism; the Enlightenment; revolutions; capitalism; Marxism, communism \& socialism; the nation state; genocide. 58 In the section "Notions of Progress and Superiority." 


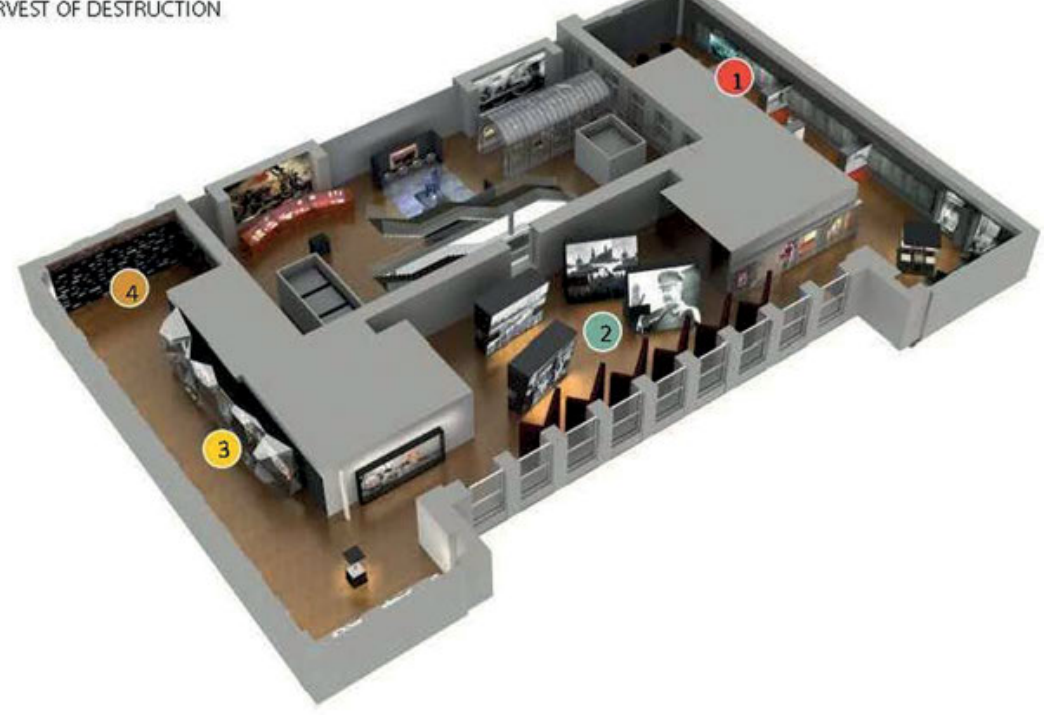

Fig. 24 Floor plan of floor 3 "Europe in Ruins." Permanent Exhibition. House of European History, Brussels (Photo and (C) House of European History).

alism / totalitarianism evolved. This is highlighted in an installation simultaneously playing films on Soviet and German totalitarianisms in the section "Totalitarianism versus Democracy," supplemented by two large object vitrines each (see also Mork 2018, 159-162). This exhibition creates a differentiated comparison between the National Socialist and the Soviet totalitarian systems by, on the one hand, emphasizing their structural similarities such as leadership, methods of terror, inclusion and exclusion, and mass rallies. It also highlights the supremacy of the collective and the creation of the need to belong. On the other, it examines differences between the systems, such as the different economic systems, the importance of race for the Nazi and class for the Soviet ideology as well as the varieties of terror, e.g. in the Holocaust and Gulag experiences. Unlike in the MIIWŚ, there is no immediate agent - such as Poland - situated between the two totalitarian systems. The last set of images cuts between concentration camp prisoners behind barbed wire and famine victims in the Soviet Union. This has the effect of symbolically connecting the victims of terror under both regimes. If there is a guiding principle to these totalitarianisms, it is the destruction of hu- 
manity and the European values named at the beginning of the museum's exhibition. $^{59}$

A small display case on the Spanish Civil War, located directly before the Second World War section, demonstrates the consequences of the two totalitarian systems assessing each other's strengths in a limited arena. The visitor encounters the bronze sculpture Guernica by René Iché from 1937, based on his daughter: it depicts a single skeletal young girl expressing terror after the German bombing of her town, symbolizing the most innocent victims of this attack on civilians (Christodoulou 2018, 232). The artwork can affect the visitor as a form of autonomous art, expressing horror (from the perspective of the figure as well as for the observer). The girl's eyes are seemingly empty, her nose is cut off, and her teeth are sticking out. Two distorted shadows of the figure are created on the wall behind it, increasing the statue's horrifying effect. At the same time, the artwork is functionalized in the context of the museum's narrative, as it allows for a transition into the Second World War section, which focuses on the fact that this conflict was a catastrophe for civilian victims on all sides. $^{60}$

The HEH creates a fairly universal Second World War section, which consists of three sections (see also Mork 2018, 162-168). Similarly to the MIIWŚ, its guiding principle - as seen in the survey text on the tablet - is total war that abandoned the distinction between soldiers and civilians. It highlights universal phenomena such as mass execution, deportation, starvation, forced labor, concentration camps, and bombings. The parallels between the brutal effects of National Socialism and Stalinism are mentioned, as is the status of the Holocaust as "an unparalleled event in history" in both "its scale and bureaucratic form." In the first part of this section, the $\mathrm{HEH}$ provides factual documentation of main events of the war, from the annexation of Austria, up until May 8/9, 1945. This is done through a timeline of newspaper headlines from different countries in their original languages and layouts, supplemented by historical photographs and maps, displayed on a table. The tablet adds factual information about each event and translates the newspaper headers. This contextualizes the featured events, while giving the visitor a sense of how different national stories were reported. The value of the latter is limited, of course, since the visitor has no further information on whether these newspapers were allowed to report independ-

59 For a complete deconstruction of the HEH's totalitarianism, see Lutz 2019.

60 See also the discussion of Iché's sculpture in chapter 9 in comparison to other art work in military history museums. 
ently and where they stood politically at the time. Instead they remain a snapshot, in order to provide the visitor with a factual frame.

The second main section covers two walls of a corridor. ${ }^{61}$ On the left hand side, the exhibition displays a fairly general film on the Air War across six screens, which shows images of planes, bombs, material destruction, and ruins. Goebbels' declaration of total war can be heard once and the film ends with a flash, following footage of the Enola Gay, indicating that the explosion of the first nuclear bomb on Hiroshima ended the war's destruction. There are almost no humans recognizable in the film; one sees German and Allied planes, though details on what exactly is being shown are impossible to discern. This means that viewers receive a very generalized, de-historicized, exclusively atmospheric and emotionalized message concerning the total destruction wrought during the Air War. ${ }^{62}$ Does it indicate that both sides were responsible for the effects of total warfare? Is there guilt in total warfare? The visitor does not receive any data to help them in answering such questions because the HEH uses a transnational technique that often negates the historical specificity of national agency.

The core part of the Second World War section is a large display covering the whole right wall of a corridor, featuring more than 200 artifacts sorted into ten thematic categories: territorial ambitions, mass shootings and massacres, mass expulsions and deportations, starvation, forced labor, concentration camps, the Holocaust, the Air War, collaboration, and resistance (see fig. 25). The objects and photographs mainly function illustratively, but they also create questions about the ways in which they can function together. Every theme is a transnational representation, combining objects from a variety of countries. Some highlight the policies of totalitarian states, i.e. Germany and to a lesser extent the Soviet Union, while the majority of the themes emphasize the civilian victims of total war.

What on the surface seems to hold similarities with the transnational strategy of the Gdańsk Museum of the Second World War (MIIWŚ) in highlighting the human cost of war, it quickly proves to be quite different. With the exception of the minimal contextualization provided on the tablet, the object tableaus lack historical specificity. Whereas the master narrative in the MIIWŚ, the historically specific chronological exhibition in the Bundeswehr Military Museum, the evidentiary structure in the Topography of Terror, and the historical focus in the

$\mathbf{6 1}$ The walls of this section are designed like a shed with a patched-up wood and brick wall, somehow indicating the fragmentary and fragile nature of life during the war.

62 The tablet only lists the copyright holders for all of the footage in the film montage; thus, it does not provide any information on which cities, air-attacks, etc. are represented. Occasionally, visitors might be able to identify specific types of planes or their emblems. 


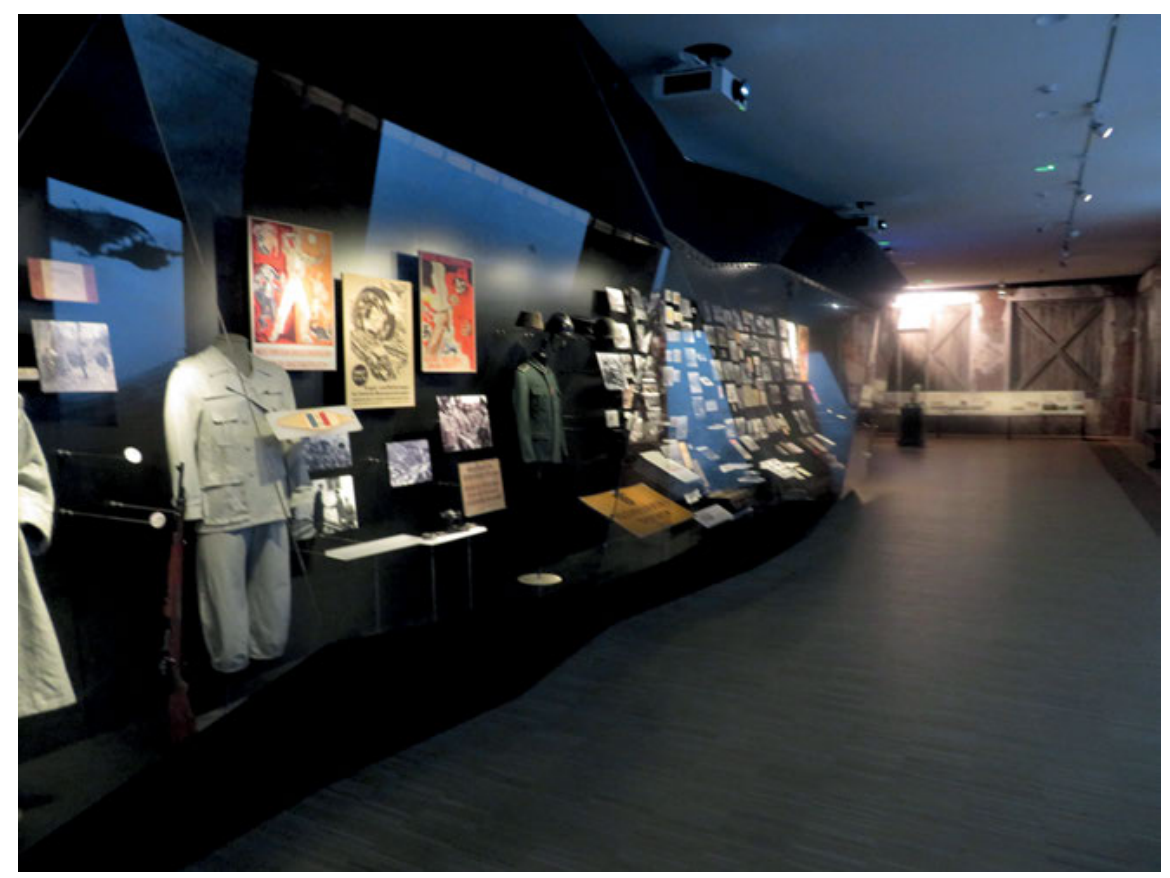

Fig. 25 "World War II" gallery. Permanent Exhibition. House of European History, Brussels (Photo: Author, 2017, courtesy of House of European History).

German Russian Museum and the Imperial War Museum North all use specific historical examples, tell stories, and allow individual voices to be heard, the HEH completely lacks such story-telling. For example, the starvation section works in a very similar way to the every-day life section in Gdańsk. Objects and photographs serve as almost arbitrary token representations of every country: The difference that this exhibition holds to the MIIWS, is that this arbitrariness of objects is present across all sections, whether it be the Air War, ${ }^{63}$ forced labor, or relocation and deportation sections.

In the latter, for example, the tablet's survey text highlights Soviet and German relocation policies as well as those of German "puppet states.” The last sentence also mentions the deportation of Jews. To illustrate this theme, the display case contains seven photographs, eleven documents, and one material object. The photographs show German settlers in the East, Polish people expelled by Germany, Slovenian people presumably expelled from Austria, Jews moving

63 See also chapter 8 below. 
into the Kaunas ghetto, Serbs expelled from Croatia, civilians expelled from Warsaw after the Uprising and destruction of the city, and Estonians deported to Nargorsk in Russia. Numerous letters from deportees, a list of deportees from Latvia, the identity card from a German 'Volksdeutscher,' a book cover on new German peasantry, and the self-made boots of a Polish deportee to Siberia complete the display. The people and their expressions in the photographs seem to resemble each other, and the letters are simply objects - they are not displayed to be read; the tablet only list captions that identify each object. No image or object is related to a story; one does not seem to distinguish itself from the next. The visitor learns that ethnic expulsions during the war were widespread among totalitarian states and their allies. However, the question of whether they were all of the same value remains (see also also Lutz 2019, 47).

The visitor can return to the two examples of the totalitarian states, Nazi Germany and the Soviet Union, in order to understand some background but overall these transnational objects remain unconnected - unlike in the MIIWS - and leave room for interpretation. Nevertheless, the museum does not allow for any networking effects to create secondary experientiality.$^{64}$ Instead, the displays express a cultural memory that highlights that many relocations and deportations took place and many people suffered from them. The transnational approach seems to merely confirm that all of Europe was impacted and that all states require a material representation in this display case. At times, the exhibition more clearly differentiates who the perpetrators were; however, the main message of the transnational displays remains that there were many forms of perpetration, suffering, and resistance and that they are all part of the narrative that moves toward a shared European cultural memory. In contrast to the HEH's mission statement, individual national stories are not displayed. There is no real alternative narrative allowing for historical specificity. The visitor is left with a very general emotional effect of total war, particularly as civilian suffering (and to a lesser extent resistance and perpetration) dominates any attempt at intellectual understanding. ${ }^{65}$

The final part of the Second World War section is entitled "The Harvest of Destruction." The visitor enters the darkened end of a corridor and views a space with numbers and stars floating along the walls and ceiling. Eleven display cabinets - like shrines - with dimmed light are visible in the dark. The introductory text on the tablet notes that an estimated 60 million people died in

64 With minimal exceptions in the resistance section.

65 One crucial difference from the MIIWŚ is the small number of photographs of casualties. The HEH displays very few corpses, and these only in specific sections like the one on mass killings. 
the Second World War, about two thirds of them civilians. It then declares that numbers alone "fail to convey the full extent of the personal tragedies involved or the catastrophic impact of these events on various group of people." Instead, the eleven objects assembled shall "tell the human story behind these events and challenge us all to consider how people come to terms with trauma and loss on such a scale." The goal of creating empathy is overly ambitious, but here the HEH clearly intends to counterbalance the universalizing effects of the previous display. To achieve this, the exhibition displays many forms of suffering through a singular object with an enlarged photograph as background of each display case. One object, for example, is a clothes hanger placed in front of a photograph of mothers, children, and elderly people standing at a set of train tracks, identified as German expellees in Poland. The text references the fate of all civilian migrants during and after the war. The coat hanger belonged to a former inhabitant of the German city of Stettin before it became the Polish city of Szczecin after the war. The visitor is asked to empathize with the fate of the expellee, as with every suffering civilian in this section. This can raise a lot imaginative questions: what can an expellee take - the background photo does not show any luggage - and what part of one's identity is left behind? The clothes hanger seems fairly general, serving as an example for millions of other refugees.

Other exhibits in the "The Harvest of Destruction" section are more personal, such as that of the teddy bear ("Tedis"). The caption of the artifact reads: "This teddy bear - a childhood reminder of happier times before the war - was owned by a young Latvian girl who passed through many of these camps until she eventually arrived in the USA, as one of the 460,000 refugees accepted into the country." The visitor can assume that the teddy bear accompanied the unnamed Latvian girl through the camps and to the United States. It signifies her safer, earlier childhood - life before the camps - and simultaneously the hope for a better future. The teddy bear works to emotionally affect the visitor, prompting them to empathize with the plight of children in war. This iconography of trauma (Arnold de-Simine 2013, 80 -86; Mikuska-Tinman 2018) allows the visitor to ask existential questions as well as questions connecting past and present. In contrast to the display case previously analyzed, the focus on material objects is here linked to the imagination of the possible worlds of individuals. The photograph behind the teddy bear shows displaced Polish nationals leaving a camp, adding a collective and universalizing dimension to the individual dimension of the stuffed animal. Does the teddy bear therefore symbolically stand for all war refugees? ${ }^{66}$

66 A similar universalization of concrete artifacts is achieved in the section's display case on the 
Of course, the focus of this section is on empathy and emotion concerning civilian suffering; the materiality of the object and - at times - a concrete story make it possible for the human imagination to grasp this suffering. In this way, it surpasses the general abstraction that dominates the previous section.

Finally, the visitor reads two quotations on the wall at the end of the "Harvest of Destruction” section. The first is by Elie Wiesel from 1986: “... if anything can, it is memory that will save humanity. For me, hope without memory is like memory without hope." The second quotation stems from Winston Churchill in 1946: "There must be ... a blessed act of oblivion. We must all turn our backs upon the horrors of the past. We must look to the future." On the one hand, the visitor can note a tension: should one forget the horrible past or remember it? On the other hand, both quotations demonstrate the idea of temporality that the HEH wants to display. Hope indicates a future. If one reads Churchill's sentence as the oblivion of all atrocities, the HEH's great focus on memory proves him wrong; if it means to leave ideas of revenge, the perception of the enemy, and the different sides of the war behind, it connects to the emerging European memory narrative. One of the building blocks of the new Europe is the human catastrophe of the Second World War.

If one defines the transnational as placing national memories and histories into constellations, as the major definition of the second type of transnationality used in this study does, one could argue that the Second World War section in the HEH does not function transnationally. Although it assembles objects and experiences from many European nations, none of these national narratives and artifacts maintains an autonomous cultural memory. Consequently, there is a clear distinction from the expression of Polish cultural memory seen in the Gdańsk Second World War Museum or the German and Soviet ones found in the German Russian Museum. This second type of transnationality, as discussed above, can overcome the challenge of memory competitions and make transnational memory more than a zero-sum game (Rothberg 2009, 3). Where, then, does the transnational set-up of the HEH lead to instead? To understand its narrative frame, it is important to go back to the fourteen principles of European heritage expressed in its introductory section. In the tablet's survey text, the museum asks: "What binds this continent together?" The three introductory sections defining Europe on the second floor (the entry floor to the permanent exhibition), are the most open parts of the museum. This is because the idea of Europe is mainly presented through artworks and constellations of objects and facts that

Air War, where a photograph of people seeking shelter in the London Underground supplements the material object of a portable air-raid siren from Germany. 
require the visitor's active interpretation. The fourteen principles or "basic elements" are presented more as something offered to the visitor than as answers to what defines Europe: "Can these be considered distinct hallmarks of European culture? If so, what parts of this European heritage should we preserve, what do we want to change, what should we contest?" Two quotations emphasize the value of memory and the dynamics of defining Europe in this section. First, the Spanish-American philosopher, poet, and humanist George Santayana is quoted: "Those who cannot remember the past are condemned to repeat it" (1905). Second, the French philosopher and theorist Julia Kristeva highlights that the process of constantly defining Europe is an integral part of its existence: "Europe is the only place in the world where identity is not a cult, but a process of questioning" (2013).

The only principle that is directly related to the Second World War and the Holocaust is "Genocide." As with all of the principles, the museum connects two exhibits from the past and present. The topic "Genocide" is marked by a German passport from 1939 marked "Jew," alongside a photograph of a woman wearing a headscarf with a non-Caucasian, i.e., ethnically 'different' woman looking at anti-immigrant graffiti with a swastika in Denmark. Here, the HEH uses the dynamics of transnational and temporal constellations in a very dynamic way. The tablet only gives a minimalistic factual introduction and captions for the exhibits. Aside from this, every one of the fourteen principles receives an approximately one-and-a-half minute audio text, in which the narrator connects the principle to its history and to Europe. These texts always end with an open-ended question for the visitor to further reflect on what the principle truly means for the European past and present. In the case of genocide, the narrator asks: "Could such inhumanity ever take place in Europe again?"67 Visitors can decide for themselves whether anti-immigrant attitudes in European countries could lead to similar inhumanities or at least represent problematic value systems. Visitors must decide whether the Holocaust is a unique form of genocide or whether they have encountered other comparable 'inhumanities' throughout the exhibition. Here, visitors are challenged to think in comparative and transnational terms from a European or humanist perspective. For the principle of democracy, the narrator asks whether democracy is a fixed part of European heritage.

67 Other questions in this section, even if the objects displayed do not directly refer to the Second World War, ask under the header "state terror": "Can an act of terror ever be justified as a means to an end or is violence of any kind unacceptable?" The "abolition of slavery" principle challenges the visitor on whether slavery is truly abolished or could be still present, while relating its formal abolition to "peaceful activism and self-criticism." 


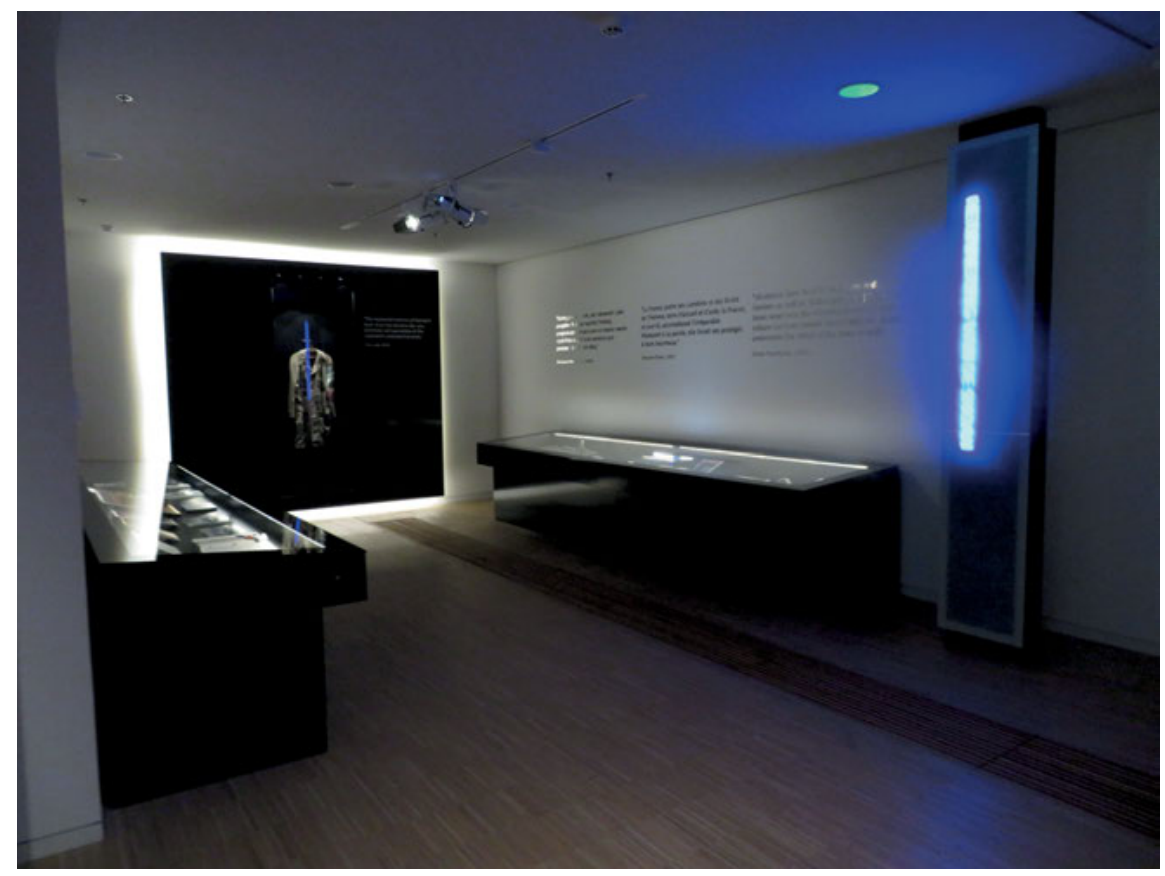

Fig. 26 Section “Memory of the Shoah.” Permanent Exhibition. House of European History, Brussels (Photo: Author, 2017, courtesy of House of European History).

These principles of European heritage occur throughout the exhibition, usually without explicit reflections. However, the HEH misses the opportunity to reflect on its open-ended questions again at the end of the exhibition. Unlike the European heritage section, the actual exhibition is far less open. This becomes clear in the memory sections, where the Holocaust and the Second World War re-appear on the fourth and fifth floors of the museum, particularly in the section "Memory of the Shoah" (see fig. 26). ${ }^{68}$ This section is comprised of six horizontal vitrines holding objects, each paired with a quotation on the challenges of post-war memories, the silence surrounding complicity, and the emphasis placed on individual national suffering in West Germany, East Germany, Austria, Poland, France, and Ukraine. All of these object arrangements are created to prove the last sentence of the section's introduction: "Today, however, the acknowledgement of this unparalleled crime against humanity is at the core of dis-

68 Chantal Kesteloot argues "the room on the memory of the Shoah is set apart from the main tour, symbolizing its longstanding marginal status” $(2018,156)$. 
cussions about a European memory." In other words, although the HEH tells six varying stories of national Holocaust remembrance, the moment they have reached the present, they are all universalized.

To further understand this process of universalization, the different object display cases need to be juxtaposed with one another. The West German one reads like a slow process of coming to terms with the past, taking place between the 1950s to late 1970s; the East German one reflects upon the fact that Jewish suffering was secondary to that of the communist resistance in the GDR. The Austrian display case highlights the narrative of Austrian victimhood, and that only since the 1980s and the Waldheim affair have the Austrians started to question this narrative of their exclusive victimhood. The Polish and Ukrainian sections emphasize that only after 1990 open memory was possible, contemplating Polish perpetration especially through the display of a copy of Jan T. Gross's Neighbors (2001 [2000]), about Polish guilt in the massacre of the Jews in Jedwabne in July 1941. The Polish display case also examines the transformations in post-Soviet memory strategies in the Concentration Camp Museum in Auschwitz and the challenges of recognizing Jews as a specific victim group. The French display expresses how long it took the French to also reflect upon the widespread collaboration and complicity in Vichy France during the Holocaust. The Ukrainian display case is truly puzzling. ${ }^{69}$ The majority of objects refer to the Babi-Yar Massacre, whose memory was erased during the Soviet period and then rediscovered after 1990. Yet there is no reflection on the Ukrainian support of German crimes, the memory of the Holodomor, or on possible new memory challenges for an independent Ukraine. No display truly reflects upon the present; it seems that all nations have come together in commemorating the Holocaust today and have all worked through their more problematic pasts. This section is indicative of how political the set-up of HEH really is, even if the curators wanted to prevent this (House of European History 2017b, 4-5). There is no word on memory tensions in Poland today. Nowhere do visitors see how fragile memory actually is (see also Lutz 2019, 46).

Even the artwork that completes the display serves the need to never forget the Holocaust. Ritula Fränkel and her husband Nicholas Morris created the artwork Jozef's Coat in 2001. The coat belonged to Rita's father Josef Fränkel, a Holocaust survivor. The artists have incorporated images and written memories into the coat "creating a testament or biographical journey of the father's harrowing wartime experiences.” The coat is an impressive artifact; it displays fam-

69 Hilmar describes how the museums planners struggled to integrate Eastern European memories and narratives into the museum's context $(2016,308)$. 
ily and vacation photographs, the Star of David, among other things. Since visitors have no exact way to interpret the photographs and other traces of Josef Fränkel's biography, they feel the mystery of the artwork and its powerful but undecipherable relation to a life between ordinary childhood, family memories, and the horrors of the Holocaust. Yet the section's master narrative makes the presence of this artwork secondary to its pragmatic purpose. ${ }^{70}$ Instead of understanding how dynamic Europe and its memory is, with all of its different influences and possible values and principles as the beginning of the exhibition and the quotation by Kristeva suggest, the leading quotation of the section by the historian Tony Judt from 2005 that is paired with the art installation is static: "The recovered memory of Europe's dead Jews has become the very definition and guarantee of the continents [sic] restored humanity." Contextualization overshadows the artwork's individuality. Transnational memory - looking into six national case-studies of Holocaust memory - does not lead to productive constellations and interpretive openness. Instead, all countries finally come together in a universal memory that allows the idea of a humanist Europe to take shape. This clarifies the implicit master narrative of the HEH in regard to the Second World War: total war, the loss of democracy, and the emergence of inhumanity led to civilian suffering. The Holocaust holds a specific status in this memory of suffering. After the war and even more so after the Cold $\mathrm{War}^{71}$, a European vision comes together. The catastrophes of the Second World War and the Holocaust are stepping-stones to a strong vision of Europe in the present. For a strong Europeanist, this might sound right, yet it shows the risks of representing the Second World War when a transnational, European master narrative simply replaces national master narratives. This museum does not build a European display that encapsulates a multiplicity of voices that also have the ability to contradict each other; it does not show how the European idea can act as an umbrella to negotiate tensions between different nation states; nor does it elude to how easily memories of the Second World War can still become matters of contention in contemporary memory politics. The exhibition's initial approach of holding openly controversial ideas that have shaped a European cultural community in tandem with one another as well as the object-based nature of this exhibition should have invited the visitor to react aesthetically to objects and interpret them in different ways. Instead, the exhibition is clearly disciplined by a linear master narrative toward contemporary European identity.

70 See also chapter 9.

71 The European Union appears as mediator in the Cold War at several stages. 
On the fifth floor, the visitor discovers the small display "Shared and Divided Memory" that should allow for a dynamic dialogue on European memory. The cube contains four display cases on each side. The survey text highlights the fact that twenty-five years after the collapse of Communism, new memories have emerged and the question "What is Europe?" has received new relevance. One piece of artwork by Yuri Leiderman (Berlin 2005/2015), entitled The Victims from Khatyn and the Victims from Katyń ... brings together two massacres: one by the Soviets near Katyń in 1940 and the one by the Nazis when they massacred the population of the Belarusian village of Khatyn/Chatyn in 1943. The artwork is supplemented by a 2005 quotation by writer Jorge Semprúm: "One of the most effective ways of moving towards a united Europe ... is ... to pool our hitherto separate memories." One case displays photographs of memorials against the Soviet dictatorship. Some memorials are new; other old Soviet memorials are reinterpreted as counter-memorials. In the end, the whole display, however, only indicates one direction for new memories: the end of Communism leading to a reinterpretation of communist memory politics. The visitor gets the feeling that this is a one-way street; now, all memories can come together. ${ }^{72}$ The HEH misses the opportunity to truly show the dynamics of memory battles, particularly in regard to the Second World War and where these can be located in a European context. Instead, there seems to be a linear road to a better, more ethical memory. As in all master narrative-based exhibitions, whether they are national, transnational, or based on other values systems, the visitor is assigned the passive role of observing developments that are represented as true. The HEH runs the risk of being read as a progressive narrative toward freedom and humanity via the medium of the European Union. This master narrative is part of the museum's architecture, which develops from the bottom (second floor) to the top of the building. The reinvention of Europe after the total destruction of the Second World War seems to highlight a constant progress to European unity and freedom, which runs parallel to the development of the European Union.

From the fourth floor onward, the visitor encounters square milestone columns displaying objects and explaining developments in the European integration process after 1945. When a column in the Cold War section explains how the Rome Treaties in 1957 established the European Atomic Energy Community "for the peaceful development of nuclear energy," it remains open as to whether this is simply a fact or specifically selected wording that establishes a master narra-

72 The only area of real memory contention is the display case of symbols of communism, which explicitly reflects on negative and positive memories employed in contemporary Europe in relation to communism. 
tive toward a human rights-based and democratic Europe. More clearly, a copy of the European convention of Human Rights in Strasbourg from 1950 fulfills this narrative. The museum notes: "For the first time, individuals could now take a state to court if they felt that their human rights had been violated, an important development to arise out of the experience of state-led terror in the preceding decade." The page on display, citing article 3, supports this: "No one shall be subjected to torture or to inhuman or degrading treatment or punishment." The Second World War is the gateway for this European development of human rights. The master narrative that views Europe and the EU as a guarantor of human rights is made even more clear, as the exhibition highlights the EU's mediating role between the United States and the Soviet Union in the Helsinki Treaty negotiations from 1975: "The European Union succeeded in introducing guarantees on human rights, which became a tool used by dissidents against Communist rule." Whether or not there is an inherent master narrative, the exhibition's objects are often on the verge of being fully functionalized to exemplify a specific historical master narrative. They could also trigger more open visitor reflections on how they fit - or not - into a European narrative, or whether or not they display the diversity of different European nations. The large collection of artwork (in comparison to other history museums) ${ }^{73}$ and the large number of quotations speak to a more open transnational approach. Whereas the Tony Judt and Jorge Semprúm quotations discussed above point to a restrictive universal memory, on the sixth and final floor, the exhibition presents several highly dialectic quotations that are seemingly more open. The Swiss writer Adolf Muschg, for example, is quoted: "What holds Europe together and what divides it is ... a common memory" (2003). Clearly, the universality of memory is not seen as a one-way road to a unifying memory here. Similarly, the American historian Jay Winter, an expert of memory and the First World War, is quoted in the final installation "Facing the Future" indicating the dynamics and possible tensions of the European integration process: "to understand the integration of Europe, ... you had to understand the disintegration of Europe" (2012). Here, the HEH again highlights the importance of memory without foreclosing its future, as in the quotation by the Ukrainian writer Yuri Andruchovych: "The formula of being human is memory plus hope" (2004). A quotation on the critical spirit "as one of essential tools of Europeans" (1994) by Jacques Le Goff is displayed in the previous section "History, Today and Tomorrow."

However, despite these tendencies toward a more open memory, a negotiation of European identities (see also Mork 2016, 232), and critical memory work,

73 See also chapter 9. 
the Second World War and the Holocaust serve as ultimate disasters and become founding myths of contemporary Europe in the permanent exhibition of the HEH (see Leggewie and Lang, 2011; Kaiser et al. 2014, 114, for the concept). Here, different memories of numerous nations become universal through a transnational presentation. Controversies that would complicate the narrative of the Second World War and create inter-European tensions - whether one looks, for example at Hungary and Poland today, or the reception of the German miniseries Generation War (Unsere Mütter, unsere Väter) in Eastern European countries (CohenPfister 2014) - do not exist, again showing how museums operate within the restraints of political discourses. Although the HEH's permanent exhibition is more dynamic in some parts, this is not the case for its representation of the Second World War. In the end, the visitors have received no means to understand why Second World War memory is still so contentious and why a transnational European discourse allows for varying national memory discourses, while at the same time generating a European universality. Consequently, the museum develops - at least regarding the representation of the Second World War - considerably less secondary experientiality than the German Russian Museum and the Gdańsk Museum of the Second World War. Despite its transnational approach, the HEH seems to return to the concept of restricted experientiality as seen above. 